ORNL/TM-13065

ENVIRONMENTAL DATA AND

ANALYSES

FOR THE

PROPOSEID MANAGEMENT OF SPENT

NUCLEAR FUEL

ON THE DOE OAK RIDGE RESERVATION

DATA PACKAGE TO SUPPORT THE

PREPARATION OF AN ENVIRONMENTAL ASSESSMENT

\author{
August 1995 \\ M. L. Socolof ${ }^{t}$ \\ M. S. Salk ${ }^{2}$ \\ A. H. Curtis ${ }^{1}$ \\ L. K. Mann ${ }^{2}$ \\ V. R. Tolbert ${ }^{2}$ \\ T. J. Blasing ${ }^{1}$ \\ Oak Ridge National Laboratory \\ Oak Ridge, Tennessee \\ 1 Energy Division \\ ${ }^{2}$ Environmental Sciences Division
}

Prepared for

Waste Management and Remedial Action Division Oak Ridge National Laboratory

Prepared by the

Oak Ridge National Laboratory

Oak Ridge, Tennessee 37831

managed by

Lockheed Martin Energy Systems, Inc.

for the

U. S. Department of Energy

under contract DE-AC05-84OR21400 


\section{DISCLAIMER}

This report was prepared as an account of work sponsored by an agency of the United States Government. Neither the United States Government nor any agency thereof, nor any of their employees, make any warranty, express or implied, or assumes any legal liability or responsibility for the accuracy, completeness, or usefulness of any information, apparatus, product, or process disclosed, or represents that its use would not infringe privately owned rights. Reference herein to any specific commercial product, process, or service by trade name, trademark, manufacturer, or otherwise does not necessarily constitute or imply its endorsement, recommendation, or favoring by the United States Government or any agency thereof. The views and opinions of authors expressed herein do not necessarily state or reflect those of the United States Government or any agency thereof. 


\section{DISCLAIMER}

Portions of this document may be illegible in electronic innage products. Images are produced from the best available original document. 


\section{TABLE OF CONTENTS}

Page

ACRONYMS AND ABBREVIATICINS $\ldots \ldots \ldots \ldots \ldots \ldots \ldots \ldots$ vii

ABSTRACT $\ldots \ldots \ldots \ldots \ldots \ldots \ldots \ldots \ldots \ldots \ldots \ldots \ldots \ldots \ldots \ldots \ldots$

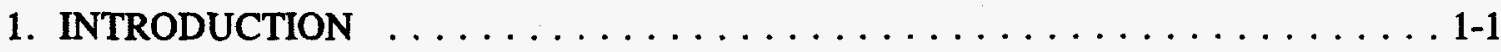

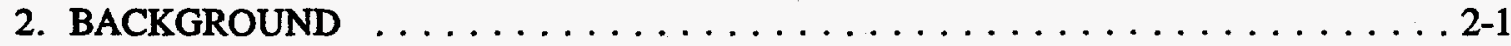

2.1 Current SNF Storagi: on ORR . . . . . . . . . . . . 2-1

2.2 Proposed Action . . . . . . . . . . . . . . . . . . . . 2-3

2.2.1 Construction of a Dry Cask Storage Facility . . . . . . . . 2-7

2.2.2 SNF Managiment Operations . . . . . . . . . . . . 2-9

2.2.2.1 Handling and repackaging $\ldots \ldots \ldots \ldots \ldots \ldots . \ldots \ldots$

2.2.2.2 Dry cask storage facility operation . . . . . . . 2-9

3. EXISTING ENVIRONMENT $\ldots \ldots \ldots \ldots \ldots \ldots \ldots \ldots \ldots \ldots \ldots \ldots \ldots$

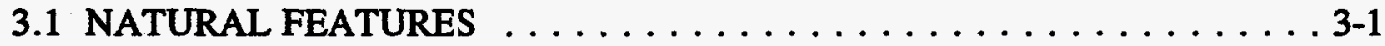

3.1.1 Oak Ridge Reservation . . . . . . . . . . . . . . 3-1

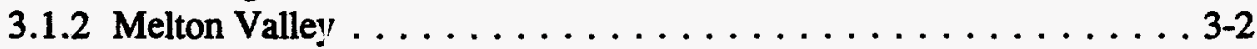

3.1.2.1 Gecilogy and soils . . . . . . . . . . . . 3-2

3.1.2.2 Grcundwater hydrology . . . . . . . . . . 3-5

3.1.2.3 Surface water $\ldots \ldots \ldots \ldots \ldots \ldots$. . . . . . . . . .

3.1.2.4 Aquatic ecology . . . . . . . . . . . . . 3-8

3.1.2.5 Terrestrial ecology/land use . . . . . . . . . . . 3-9

3.1.2.6 Historic and archaeological resources . . . . . . . . . 3-9

3.1.3 Proposed Dry Cask Facility Locations . . . . . . . . . . . . . . . 3-9

3.1.3.1 Preferred location . . . . . . . . . . . . . 3-11

3.1.3.2 Altisnative location . . . . . . . . . . . 3-12

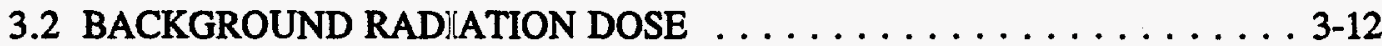

3.2.1 Public Radiation Dose $\ldots \ldots \ldots \ldots \ldots \ldots \ldots \ldots \ldots \ldots$. . . . . . . . . .

3.2.2 Occupational Radiation Dose . . . . . . . . . . . . 3-13

4. ENVIRONMENTAL IMPACTS $\ldots \ldots \ldots \ldots \ldots \ldots \ldots \ldots \ldots \ldots \ldots$ 4-1

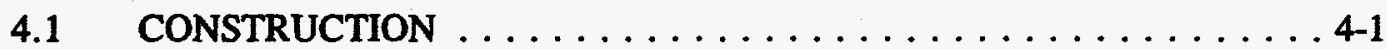

4.1.1 Preferred Site .................... . .

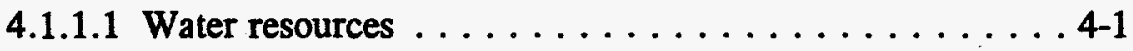

4.1.1.2 Ecological resources $\ldots \ldots \ldots \ldots \ldots \ldots \ldots \ldots$ 4-1

4.1.1.3 Health and safety $\ldots \ldots \ldots \ldots \ldots \ldots \ldots . \ldots \ldots$ 4-2

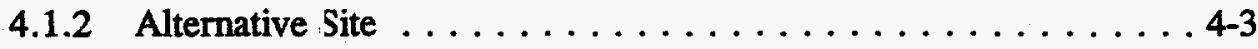

4.1.2.1 Water resources $\ldots \ldots \ldots \ldots \ldots \ldots \ldots \ldots \ldots$ 4-3

4.1.2.2 Ecological resources $\ldots \ldots \ldots \ldots \ldots \ldots \ldots \ldots$. . . . . . 
4.2 SNF NORMAL OPERATION (HANDLING/STORAGE) $\ldots \ldots \ldots \ldots$. . 4-3

4.2.1 Water Resources . . . . . . . . . . . . . . . . . . . . . 4-3

4.2.2 Ecological Resources . . . . . . . . . . . . . 4-4

4.2 .3 Health and Safety . . . . . . . . . . . . . . 4-5

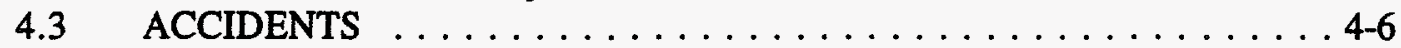

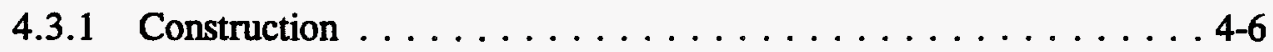

4.3 .2 Operation . . . . . . . . . . . . . . . .7

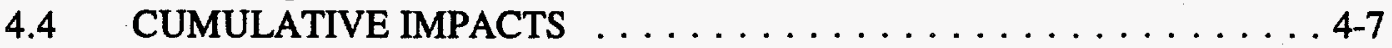

4.4.1 Groundwater Hydrology and Quality Impacts . . . . . . . . . . 4-10

4.4.2 Surface Water Hydrology and Quality Impacts . . . . . . . . . 4-10

4.4.3 Wetlands . . . . . . . . . . . . . . . . . 4-11

4.4 .4 Aquatic Ecology . . . . . . . . . . . . . . . . 4-12

4.4.5 Terrestrial Ecology $\ldots \ldots \ldots \ldots \ldots$. . . . . . . . . . 4-12

4.4.6 Air Quality . . . . . . . . . . . . . . . . . . 4-14

4.4.7 Historic and Archaeological Resources . . . . . . . . . . . 4-16

4.4 .8 Health and Safety $\ldots \ldots \ldots \ldots \ldots \ldots \ldots \ldots \ldots$ 4-16

4.4.9 Transportation $\ldots \ldots \ldots \ldots \ldots \ldots \ldots \ldots \ldots \ldots$ 4-18

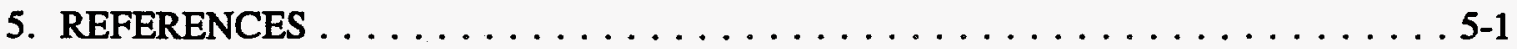

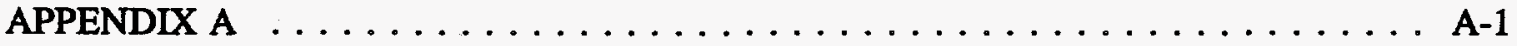

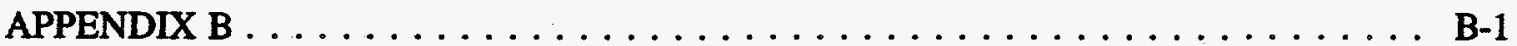




\section{FIGURES}

1.1 General location of the DOE Oak Ridge Reservation in Oak Ridge, Tennessee . . . . . . . . . . . . . . . . . . . . . . . . . 1-2

2.1 Oak Ridge National Laboratory waste and spent nuclear fuel storage locations . . . . . . . . . . . . . . . . . . . . . . 2-6

2.2 Proposed sites for the dry cask storage facility $\ldots \ldots \ldots \ldots \ldots \ldots \ldots \ldots$

3.1 Generalized geologic map of the Oak Ridge, Tennessee area . . . . . . . . 3-3

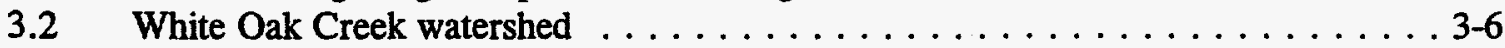

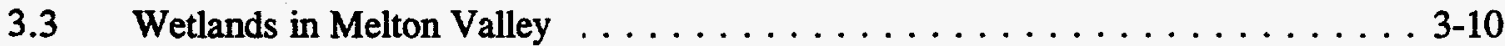

4.1 Site locations for Oak Ridge National Laboratory's proposed waste management projects for Melton Valley through $1995 \ldots \ldots \ldots$. . . . 4-8

\section{TABLES}

2.1 Spent nuclear fuel on the Oak Ridge Reservation, Oak Ridge, Tennessee . . . . . 2-4

2.2 Summary of spent nuclear fuel (SNF) handling activities $\ldots \ldots \ldots \ldots \ldots \ldots$ 2-10

3.1 Strontium titanate soil contasnination in Solid Waste Storage Area $7 \ldots \ldots$. . . 3-5

3.2 United States individual bacliground radiation effective dose equivalents (EDEs) $\ldots \ldots \ldots \ldots \ldots \ldots \ldots \ldots \ldots$. . . . . . . . . . . .

3.3. Annual radiation effective dose equivalents (EDEs)

from ORR and ORNL 
\begin{tabular}{l} 
A \\
\hline \\
\hline \\
\hline
\end{tabular} 


\section{ACRONYMS AND ABBREVIATIONS}

\begin{tabular}{|c|c|}
\hline ALARA & as low as reasonably achievable \\
\hline $\mathrm{Bq}$ & Becquerel \\
\hline BSR & Bulk Shielding Reacior \\
\hline CERCLA & Comprehensive Environmental Response, Compensation, and Liability Act \\
\hline $\mathrm{CH}$ & contact-handled \\
\hline $\mathbf{C i}$ & Curie \\
\hline $\mathrm{cm}$ & centimeter \\
\hline DOE & U. S. Department of Energy \\
\hline dpm & disintegrations per minute \\
\hline EA & Environmental Assessment \\
\hline EDE & effective dose equivalent \\
\hline EIS & Environmental Impact Statement \\
\hline FWS & U. S. Fish and Wildilife Service \\
\hline Gy & gray \\
\hline HFIR & High Flux Isotope Reactor \\
\hline in. & inch \\
\hline kg & kilogram \\
\hline LLLW & liquid low-level waste \\
\hline mGy & milligray \\
\hline mrem & millirem \\
\hline MSRE & Molton Salt Reactor Experiment \\
\hline $\mathrm{mSv}$ & millisievert \\
\hline MW & megawatt \\
\hline NEPA & National Environmental Policy Act \\
\hline NPDES & National Pollutant Discharge Elimination System \\
\hline NRC & U. S. Nuclear Regulatory Commission \\
\hline ORNL & Oak Ridge National Laboratory \\
\hline ORR & Oak Ridge Reservation \\
\hline ORRR & Oak Ridge Research Reactor \\
\hline OSHA & Occupational Safety and Health Administration \\
\hline $\mathrm{pCi}$ & picoCurie \\
\hline PEIS & Programmatic Environmental Impact Statement \\
\hline RH & remote-handled \\
\hline ROD & Record of Decision \\
\hline SLLW & solid low-level wasti: \\
\hline SNF & spent nuclear fuel \\
\hline${ }^{90} \mathrm{SrTiO}_{3}$ & strontium-90 titanate: \\
\hline Sv & sievert \\
\hline SWSA & solid waste storage area \\
\hline TRU & transuranic \\
\hline TSR & Tower Shielding Reactor \\
\hline
\end{tabular}




\begin{abstract}
On June 1, 1995, U.S. Department of Energy (DOE) issued a Record of Decision (ROD) for a programmatic environmental impact statement (PEIS) regarding management of DOE-owned spent nuclear fuel (SNF). The preferred alternative in the ROD is to regionalize the management of SNF located throughout the DOE complex on the basis of fuel type. The DOE ORR currently maintains an inventory of SNF and will continue to generate SNF from operation of the High Flux Isotope Reactor.

DOE needs to continue the siafe and efficient management of SNF on ORR, based on the requirement for future SNF storage capacity and implementation of the ROD for the PEIS. DOE is proposing to implement the ROD through proper management of SNF on ORR, including the possible construction and operation of a dry cask storage facility. This report describes the potentially affected environment and analyzes impacts on various resources due to the proposed action. The information provided in this report is intended to support the Environmental Assessment being prepared for the proposed activities.

Construction of the dry cask storage facility would result in minimal or no impacts on groundwater, surface water, and ecological resources. Contaminated soils excavated during construction would result in negligible risk to human health and to biota. Except for noise from trucks and equipment, operation of the dry cask storage facility would not be expected to have any impact on vegetation, wildlife, or rare plants or animals. Noise impacts would be minimal. Operation exposures to the average SNF storage facility worker would not exceed approximately $0.40 \mathrm{mSv} /$ year $(40 \mathrm{mrem} /$ year). The off-site population dose within an $80-\mathrm{km}$ (50-mile) radius of ORR from SNF (perations would be less than 0.052 person-Sv/year (5.2 person-rem/year). Impacts fronı incident-free transportation on ORR would be less than $1.36 \times 10^{-4}$ occupational fatal cancers and $4.28 \times 10^{-6}$ public fatal cancers. Credible accident scenarios that would result in the greatest probable risks would cause less than one in a million cancer fatalities to workers and the public.

The cumulative impacts from the implementation of several actions in Melton Valley are expected to result in minimal or 10 cumulative adverse impacts to groundwater, surface water, aquatic biota, wetlands, air quality, and human health. State-listed wildlife populations known to use forest ecosystems such as those affected by these projects are assumed to be affected by additive fragmentation and effects of loss of habitat. The overall impact on the wildlife habitats would be relatively small. However, the projects in Melton Valley add to progressive fragmentation of forest on ORR which could have a disproportionately negative effect on interior forest populations and migratory bird species in the region. Some projects, not specifically included in this analysis, would impact large areas. In total, therefore, the actions in Melton Valley, in addition to all the other on-going and potential actions on ORR, could have considerable cumulative impact on ORR vegetation and wildlife.
\end{abstract}




\section{INTRODUCTION}

The management of spent nuclear fuel (SNF) includes establishing, operating, and managing facilities, transportation sy'stems, and procedures to ensure safe and environmentally responsible handling and storage of SNF pending ultimate disposition. On June 1, 1995, the U. S. Department of Energy (DOE) issued a Record of Decision (ROD) (60 Fed. Reg. 28680) for a programmatic environmental irnpact statement (PEIS) (DOE 1995c) regarding management of DOE-owned SNF. The preferred alternative in the ROD is to regionalize the management of SNF located throughout the DOE complex on the basis of fuel type. Under the ROD, aluminum-clad SNF would be: transported to the Savannah River Site in South Carolina, and nonaluminum-clad SNF, with the exception of the production reactor fuel at Hanford, would be transported to the Idaho National Engineering Laboratory. The DOE Oak Ridge Reservation (ORR) in Tennessee (Fig. 1.1), managed by Lockheed Martin Energy Systems (Energy Systems), currently maintains an inventory of aluminum-clad and non-aluminum-clad SNF and will continue to generate SNF from operation of the High Flux Isotope Reactor (HFIR). The current storage capacity for HFIR fuel is not adequate for the next 40 years of operation.

DOE needs to continue the safe and efficient management of SNF on the ORR, based on the requirement for future SNF storage capacity and implementation of the ROD for the PEIS. DOE is proposing to implement the ROD through proper management of SNF on the ORR. The proposed action would involve on-site handling activities prior to off-site shipment; off-site shipment; and the possible on-site construction and operation of a dry cask storage facility as needed. Impacts at Savarnah River or Idaho National Engineering Laboratory are included in the PEIS and are beyond the scope of this data package. The information provided in this report is intended to support the Environmental Assessment (EA) being prepared for the proposed activities as required by the National Environmental Policy Act of 1969 (NEPA).

This data package provides a background discussion of SNF activities on ORR, describes the proposed handling and storage activities, describes the existing environment, and evaluates the impacts on the human environment of implementing DOE's ROD on the SNF Management PEIS. Only impacts fiom construction, handling, and storage activities are within the scope of this report. Analyses of on-site and off-site transportation, and socioeconomics are not included in the scope of this report. 


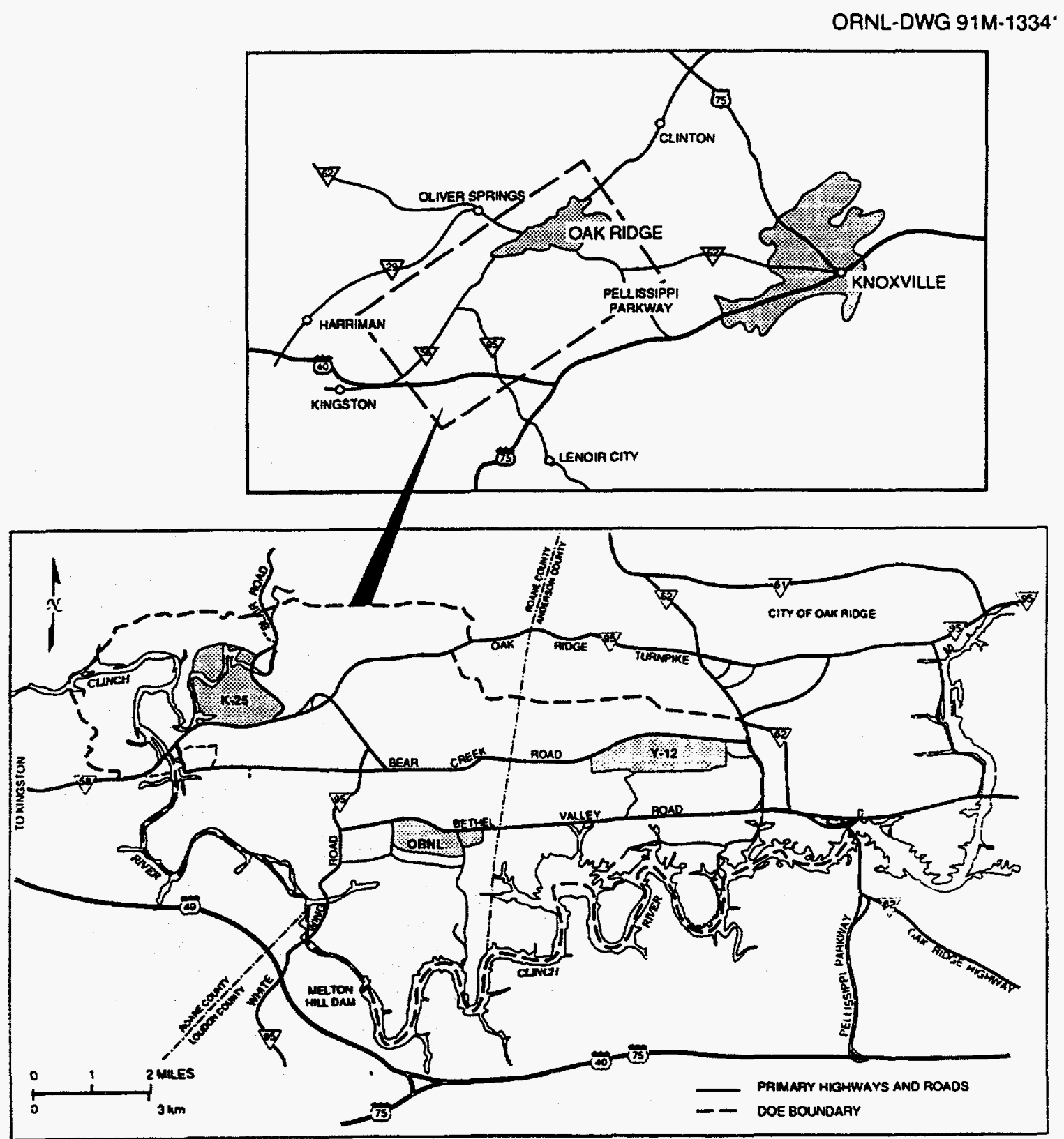

Fig. 1.1. General location of the DOE Oak Ridge Reservation in Oak Ridge, Tennessee. 


\section{BACKGROUND}

\subsection{Current SNF Storage on ORR}

Twelve facilities that have either generated or stored SNF on the ORR are described below (see also DOE 1995c: PEIS, Appendix F - ORR, pp. 3.2-8 through 3.2-16). SNF on the ORR is primarily generated by the HFIR, the world's primary or sole source for several important isotopes. The HFIR is the only ORR facility that currently generates new SNF, in addition to storing the fuel. Two facilities, the Oak Ridge Research Reactor (ORRR) and Building 4501 (High-Level Radiochemical Laboratory) no longer contain any SNF. Two facilities, solid waste storage area (SWSA) 6 and the Molten Salt Reactor Experiment (MSRE), contain SNF but will not be included in the scope of the EA or this report because they are Comprehensive Environmental Response, Compensation, and Liability Act (CERCLA) sites, and future actions will be determined through the CERCLA process. The remaining seven facilities currently store SNF but do not generate additional fuel. A description of each facility is provided below.

(1) High Flux Isotope Reactor - The HFIR is an operating beryllium-reflected, lightwater-cooled and -moderated, flux-trap-type reactor. The reactor uses aluminum-clad fuel plates containing highly enriched uranium-235. Since 1985, HFIR spent fuel has been stored in pools at the HFIR facility. At the present time 62 fuel assemblies are being stored. Currently, the remaining storage space for SNF after reracking the pool would not be adequate for 40 years of operation. If alternative storage is not provided, the HFIR would have to be shut down, stopping the supply of critical isotopes used in industry and nuclear medicine. If the reactor continues operation through the year 2035, the predicted SNF production will be approximately an additional 480 fuel assemblies.

(2) Tower Shielding Reactor No. II and Tower Shielding Facility (Building 7708) -The 1-MW Tower Shielding Reactor (TSR) No. II is a light-water-moderated, movable-tank research reactor which was shut down in 1992. At this time, there are no plans for resuming operations. TSR No. II has no containment and was used at ground level or suspended from towers. The research included testing shielding designs and obtaining associated data. The reactor was placed in standby in September 1992 pending DOE direction to prepare the facility for shutdown. At that time, the only existing fuel assembly for the reactor was being stored in the reactor containment. For handling and storage purposes, an elemen: is an integral core assembly composed of 4 upper central plates, 4 lower central plates, 12 annular plates, a central plug, and 4 fuel plates. One element is being stored in wit storage in the reactor containment. Because this reactor is shut down, no additional slements are expected to be generated through the year 2035. 
(3) Bulk Shielding Reactor -- The 2-MW Bulk Shielding Reactor (BSR) is an open-pool, light-water-moderated and -reflected training and research reactor. This reactor was built in 1951 and shut down in 1991; at this time, there are no plans for resumption of operations. The BSR currently has no elements in the reactor or in on-site dry storage. Seventy-three of 90 storage locations are occupied in the on-site wet storage in the BSR pool, containing 41 elements from the BSR and 32 elements from the ORRR (see Item 12 , below). No additional fuel is expected to be added to the inventory through the year 2035; therefore, no expansion of storage facilities on-site is expected.

(4) Building 3525-Irradiated Fuels Examination Laboratory - This two-story brick structure was built in 1963 and contains hot cells. The facility mission has been disassembly and examination of irradiated fuel and components. Building 3525 contains research reactor fuel in the form of fuel samples and targets.

(5) Building 7920 - Radiochemical Engineering Development Center -- This building is a multipurpose hot cell facility with equipment, shielding, and containment provisions to safely process and store significant quantities of SNF from the HFIR. Building 7920 contains research reactor fuel in the form of fuel samples in dry storage.

(6-8) SWSA 5 Dry Storage: Facilities 7823A, 7827, and 7829 - The storage configurations for these shielded, retrievable storage facilities are stainless-steel dry wells placed below grade in Solid Waste Storage Area (SWSA) 5 North. They vary from 20 to $76 \mathrm{~cm}$ ( 8 to $30 \mathrm{in}$.) in diameter and from 3 to $4.6 \mathrm{~m}$ (10 to $15 \mathrm{ft}$ ) in depth. The caissons were placed on a concrete pad and held in place by concrete slabs and are surrounded by soil or concrete. Spent fuel and other materials were placed in the storage positions beginning in 1972 . Activities to address the vulnerabilities in these facilities include (1) transferring the fuel, (2) adding a new inner liner and relocating materials to modified units, and (3) overpacking any fuel in suspect condition. These activities are scheduled to be completed in Fiscal Year 1996.

(9) SWSA 6 - KEMA Suspension Test Reactor Fuel - The KEMA Suspension Test Reactor (located in the Netherlands) was an experimental fluidized bed test reactor. The fuel, consisting of one can of microspheres in a grout, was placed in SWSA 6. The area of SWSA 6 where the fuel was placed is being managed by DOE as part of waste area grouping 6, an environmental restoration program activity, under CERCLA.

(10) Molten Salt Reactor Experiment - The MSRE operated from June 1965 to December 1969 at a nominal power of $8 \mathrm{MW}$. The purpose of the reactor was to test the practicality of a molten-salt reactor concept for central power station applications. The circulating fuel solution was a mixture of fluoride salts containing uranium fluoride as the fuel. The initial charge was uranium-235, but this was later replaced with a charge of uranium-233. Processing capabilities were included as part of the facility for on-line fuel additions, removal of impurities, and uranium recovery. Following reactor shutdown, the fuel and flush salts were drained to critically safe storage tanks and isolated. 
The SNF inventory at the MSRE consists of approximately $4650 \mathrm{~kg}(9514 \mathrm{lb})$ of fuel salt mixture in dry storage. 'The uranium salt is predominantly uranium-233 [31 kg (68 lb)] with lesser amounts of uranium-234, uranium-235, uranium-238, and plutonium-239. The balance of the fuel salt is composed of lithium fluoride ( $\mathrm{LiF}$, $64.5 \%)$, beryllium fluoride $\left(3 \mathrm{eF}_{2}, 30.3 \%\right)$, and zirconium fluoride $\left(\mathrm{ZrF}_{4}, 5.0 \%\right)$. Since the reactor is shut down, no additional SNF is expected to be generated through the year 2035. The MSRE is considered a CERCLA site and is awaiting decommissioning and decontamination. Therefore, future actions on the MSRE will be determined through the CERCLA process. This EA will not address the future management of the MSRE SIJF.

(11) Building 4501 - High-Level Radiochemical Laboratory - Constructed in 1951, this facility contains centrally located hot cells supported by various laboratories capable of handling radioactive materials. The SNF that was in dry storage at this facility was canned and moved to dry sto rage in Facility 7827 . Building 4501 no longer contains SNF (Klein 1995).

(12) Oak Ridge Research Reactor - The ORRR was shut down permanently in 1987 and has been defueled. Most of the fuel was transported to the Savannah River Site, but some of the fuel was transferred to the BSR pool (see Item 3, above). No SNF is currently stored at the ORRR, and the facility is therefore not in the scope of this EA.

A summary of SNF storage at these locations on the ORR is provided in Table 2.1. The general locations can be found on Fig. 2.1. The BSR, ORRR, and Buildings 3525, 3047, and 4501 are located in the main Oak Riclge National Laboratory (ORNL) complex, which is in Bethel Valley. The remaining areas are within Melton Valley. The HFIR (Building 7900), Building 7920, and the MSRE are located between SWSAs 5 and 7 in the HFIR Complex. The TSR is southeast of the HFIR Complex.

\subsection{Proposed Action}

The proposed action is to implement the ROD of the PEIS for SNF management at the ORR (see Sect. 1). This action would include (1) possible construction of a dry cask storage facility as contingency storage; (2) onl-site packaging, transport, and storage for all SNF on the ORR; and (3) off-site transport of SNF to Savannah River and Idaho National Engineering Laboratory, which is described in decail in the PEIS and therefore not described here. 
Table 2.1. Spent nuclear fuel on the Oak Ridge Reservation, Oak Ridge, Tennessee

\begin{tabular}{|c|c|c|c|c|c|c|c|}
\hline Facility Name & Facility Description & $\begin{array}{l}\text { Material Stored at } \\
\text { Facility }\end{array}$ & $\begin{array}{c}\text { No. of } \\
\text { items }\end{array}$ & Units & $\begin{array}{c}\text { Mass } \\
\text { (metric } \\
\text { tons) }\end{array}$ & $\begin{array}{l}\text { Volume } \\
\left(\mathrm{m}^{3}\right)\end{array}$ & $\begin{array}{l}\text { Heavy Metal } \\
\text { Mass } \\
\text { (metric tons of } \\
\text { heavy metal) }\end{array}$ \\
\hline \multicolumn{8}{|c|}{ FACILITIES WITHIN THE SCOPE OF THIS DOCUMENT } \\
\hline $\begin{array}{l}\text { High Flux Isotope Reactor } \\
\text { (HFIR) }\end{array}$ & $\begin{array}{l}\text { Operating research } \\
\text { reactor; wet storage }\end{array}$ & HFIR fuel & 62 & elements & 8.674 & 7.38 & 0.626 \\
\hline Tower Shielding Reactor (TSR) & $\begin{array}{l}\text { Reactor shut down in } \\
\text { 1992; wet storage }\end{array}$ & TSR fuel & 1 & assembly & 0.182 & 0.1 & 0.009 \\
\hline Bulk Shielding Reactor (BSR) & $\begin{array}{l}\text { Reactor shut down in } \\
\text { 1991; wet storage }\end{array}$ & BSR \& ORRR fuel & 73 & elements & 0.2367 & 0.39 & 0.059 \\
\hline $\begin{array}{l}\text { Bldg. } 3525 \text { - Irradiated Fuels } \\
\text { Examination Laboratory }\end{array}$ & $\begin{array}{l}\text { Hot cell facility; dry } \\
\text { storage }\end{array}$ & Misc. fuel samples & 1 & unit & 0.001 & 0.1 & 0.0001 \\
\hline $\begin{array}{l}\text { Bldg. } 7920 \text { - Radiochemical } \\
\text { Engineering Development Center }\end{array}$ & $\begin{array}{l}\text { Hot cell facility; dry } \\
\text { storage }\end{array}$ & Dresden-1 fuels & 2 & cans & 0.0057 & 0.1 & 0.004 \\
\hline $\begin{array}{l}\text { Solid Waste Area } 5 \text { North: } \\
\text {-- Facility } 7823 \mathrm{~A}\end{array}$ & Dry storage facility & Misc. fuel & 9 & cans & 0.175 & 1.2 & 0.0019 \\
\hline - Facility 7827 & Dry storage facility & $\begin{array}{l}\text { Al-, stainless steel-, \& } \\
\text { zircalloy-clad fuels, Peach } \\
\text { Bottom fuel }\end{array}$ & 67 & cans & 2.009 & 3.68 & 0.156 \\
\hline -- Facility 7829 & Dry storage facility & Peach Bottom fuel & 14 & cans & 0.552 & 1.15 & 0.0161 \\
\hline TOTAL & & & & & 11.84 & 14.1 & 0.872 \\
\hline
\end{tabular}


Table 2.1. (cont.)

\begin{tabular}{|c|c|c|c|c|c|c|c|}
\hline Facility Name & Facility Description & $\begin{array}{l}\text { Material Stored at } \\
\text { Facility }\end{array}$ & $\begin{array}{l}\text { No. of } \\
\text { items }\end{array}$ & Units & $\begin{array}{l}\text { Mass } \\
\text { (metric } \\
\text { tons) }\end{array}$ & $\begin{array}{l}\text { Volume } \\
\left(\mathrm{m}^{3}\right)\end{array}$ & $\begin{array}{l}\text { Heavy Metal } \\
\text { Mass } \\
\text { (metric tons of } \\
\text { heavy metal) }\end{array}$ \\
\hline \multicolumn{8}{|c|}{ FACLITIES OUTSIDE THE SCOPE OF THE DOCUMENT } \\
\hline Solid Waste Storage Area 6 & Disposal facility & $\begin{array}{l}\text { KEMA Suspension Test } \\
\text { Reactor fuel }\end{array}$ & 1 & pipe & 0.132 & 0.01 & 0.023 \\
\hline $\begin{array}{l}\text { Molten Salt Reactor Experiment } \\
\text { (MSRE) }\end{array}$ & $\begin{array}{l}\text { Reactor closed in 1969; } \\
\text { dry storage }\end{array}$ & MSRE fuel' & 1 & core & 8.940 & 1.81 & 0.038 \\
\hline $\begin{array}{l}\text { Bldg. } 4501 \text { - High-Level } \\
\text { Radiochemical Laboratory }\end{array}$ & $\begin{array}{l}\text { Hot cell facility; dry } \\
\text { storage }\end{array}$ & $\begin{array}{l}\text { None (misc. fuels canned } \\
\text { and moved to dry storage in } \\
\text { Facility 7827) }\end{array}$ & 0 & & 0 & 0 & 0.00 \\
\hline Oak Ridge Research Reactor & $\begin{array}{l}\text { Reactor shut down in } \\
1987 \text { and defueled }\end{array}$ & $\begin{array}{l}\text { None (moved to the } \\
\text { Savannah River Site or BSR } \\
\text { pool) }\end{array}$ & 0 & & 0 & 0 & 0.00 \\
\hline
\end{tabular}


2-6

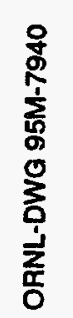

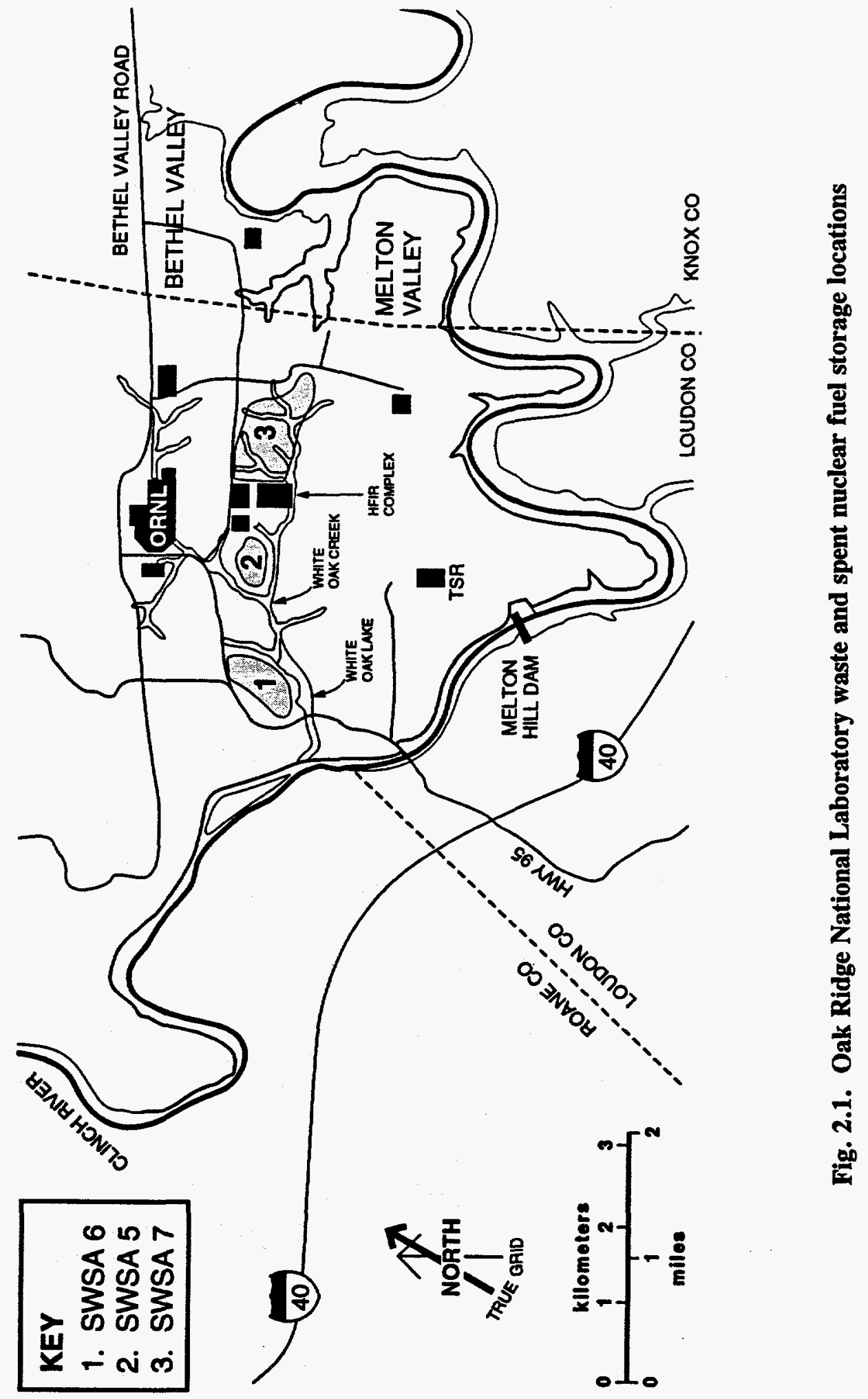




\subsubsection{Construction of a Dry Casks Storage Facility}

A new facility would only he constructed if the presently stored SNF, or that to be generated, could not be shipped to the Savannah River Site or Idaho National Engineering Laboratory in a timely fashion. The dry cask storage facility would be designed to house SNF currently stored in eight locations or the ORR (HFIR, TSR, BSR, Bldgs. 3525 and 7920, and Facilities $7823 \mathrm{~A}, 7827$, and 7829). If necessary, the proposed facility could also store other materials defined (currently or in the: future) as SNF from the ORR (e.g., material at the Y-12 Plant on the ORR) as well as KEMA. and MSRE fuels, which are being addressed in the CERCLA process. The storage facility would also be designed to store SNF generated from the HFIR in the future (at a rate of approximately one fuel element per month for 40 years). The facility would be designed for 40 years of operation and would be NRC-licensable (i.e., it would meet the requirements in 10 (CFR 72).

In a dry storage system, cooling is provided by heat transfer to the inner wall of the storage system, with eventual heat rijection to the air surrounding the storage system. Dry storage systems are mature technologies that are being applied at U. S. commercial and foreign nuclear electric generating systems. The design of this proposed facility has not been finalized; however, a stand-alone modular dry cask storage facility is preferred. With this type of system, casks can be added as needed. A modular dry cask system is preferred since Oak Ridge has a relatively small quantity of SNF to store and since HFIR is still generating spent fuel and incremental additions could be readily made as needed. A number of large standalone casks are available in the DOI: system and in commercial applications. The casks are top- or end-loading, are made from a variety of materials, and have been developed primarily in North America and Europe. Sorie cask designs are licensed for off-site transport of SNF, and others are used principally for on-site fuel movement. There are also a variety of smaller stand-alone casks that are designed jrimarily for on-site transportation and storage of specific irradiated fuels and other materials. Hot cells are also used for dry storage but are generally not considered cost efficient for storing significant quantities of SNF because of the cost of preparing the hot cells for SNF storige and the operation and maintenance costs.

An Energy Systems-led site selection committee screened six possible locations for the dry cask storage facility (Fig. 2.2). The committee chose a preferred site (HFIR West Site) and an alternative site (SWSA 5 Site), based on health and safety, functional, environmental, and

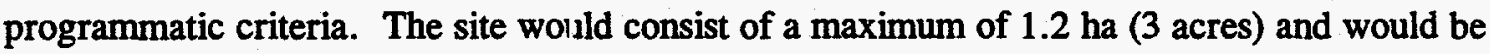
cleared and graded for construction. The facility would be constructed in a modular fashion, adding storage space as the need arcise. If the maximum facility size were constructed at one time, construction would occur during a two-year period, possibly beginning in 1999 . Approximately 10 construction workers would be needed for construction activities. The facility would be a reinforced concrete pad to hold the casks with a gravel area for cask loading and unloading. The entire facility would be within a double security fence. 


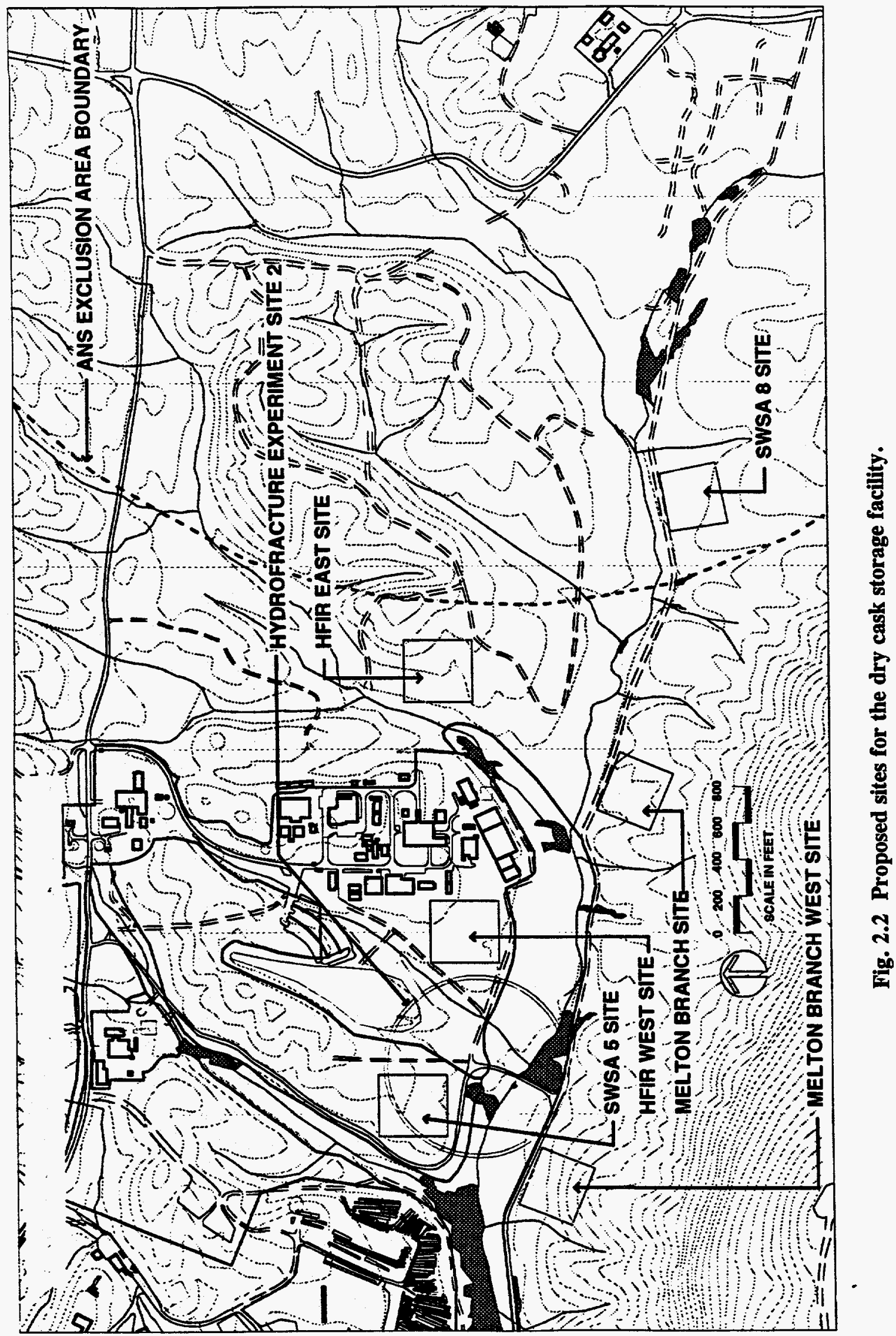


Design specifications of the dry cask storage facility ensure that the area be $1.8 \mathrm{~m}(6 \mathrm{ft})$ above the seasonal high level of the groundwater table and above the 100-year floodplain. Soil would be monitored by Health Physics and Industrial Hygiene personnel to ensure safety during excavation activities, in accordance with ORNL/M-116/R1, Health, Safety, and Environmental Protection for Excavating Operations (ORNL 1988).

\subsubsection{SNF Management Operations}

Operational activities analyzed in this report include (1) handling and repackaging SNF and (2) storage of SNF in the dry cask storage facility. These activities are described in the following sections.

\subsubsection{Handling and repackaging}

Handling activities could differ among different types of SNF. For example, aluminum-clad SNF would require repackaging prior to storage or off-site transport, while other SNF would not. The SNF might also need to be placed in interim storage at the proposed dry cask storage facility prior to off-site shipment. When off-site transport is imminent, the shipment would need to be transloaded into an off-site shipping cask.

Repackaging activities woull be conducted in hot cells designed for remote manipulation of radioactive materials. These activities would require two to three technicians and could take up to one work week (40 hours) per can of SNF. It is expected that most repackaging would be conducted in Building 3525. HFIR, BSR, and ORRR SNF would not require repackaging. The possible repackaging locations for ORR SNF are listed in Table 2.2 (column 4).

Several locations on the ORR could serve as transloading facilities (Table 2.2, column 5). For example, SNF in SINSA 5 could be transloaded at SWSA 5, Facility 3047, or Facilities 7920/30. TSR fuel could be transloaded at BSR, TSR, HFIR, or Facility 3047 . Onsite transport would involve a crew of about 5 workers. Transport from one location to another (e.g., existing storage to repackaging facility) would take no longer than one work day (8 hours). The number of shipments a):e also shown in Table 2.2 (column 6).

\subsubsection{Dry cask storage facility operation}

The dry cask storage facility would house storage casks and would not require constant attendance by operating personnel. The facility would only be occupied during transfers of SNF to the facility. Stormwater runoff would likely be collected and monitored to verify compliance with National Pollutant Discharge Elimination System (NPDES) permit requirements. Radiation exposure of operations personnel in the storage area would be in 
compliance with 10 CFR 20 ("Standards for Protection Against Radiation") and 40 CFR 191 ("Environmental Radiation Protection Standards for Management and Disposal of Spent Nuclear Fuel, High-level, and Transuranic Radiation Wastes"). To meet ALARA (as low as reasonably achievable) goals, the maximum dose rate to operations personnel from the highestactivity SNF could not exceed $2.5 \mathrm{mrem} / \mathrm{h}$. A radiological alarm system would be provided in accessible work areas, and a criticality monitoring system would be provided and maintained in the storage facility where special nuclear material (e.g., plutonium) would be stored or handled.

Table 2.2 Summary of spent nuclear fuel (SNF) handling activities

\begin{tabular}{|c|c|c|c|c|c|}
\hline Facility Name & $\begin{array}{l}\text { No. of } \\
\text { items of } \\
\text { SNF }\end{array}$ & Units & $\begin{array}{l}\text { Possible } \\
\text { repackaging } \\
\text { locations }\end{array}$ & $\begin{array}{l}\text { Possible transloading } \\
\text { locations }\end{array}$ & $\begin{array}{l}\text { Maximum } \\
\text { no. of } \\
\text { shipments }\end{array}$ \\
\hline HFIR & 62 & elements & $\mathbf{n} / \mathbf{a}$ & HFIR pool & $542^{2}$ \\
\hline TSR & 1 & assembly & $\begin{array}{l}\text { TSR, BSR, HFIR, } \\
\text { Facil. } 3047\end{array}$ & $\begin{array}{l}\text { TSR, BSR, HFIR, } \\
\text { Facil. } 3047\end{array}$ & 23 \\
\hline BSR & 73 & elements & $\mathbf{n} / \mathbf{a}$ & $\begin{array}{l}\text { HFIR, Facil. 3047, } \\
\text { ORRR (Bldg. 3042) }\end{array}$ & 73 \\
\hline Bldg. 3525 & 1 & unit & $\begin{array}{c}\text { Bldg. } 3525 \text {, Bldg. } \\
3019\end{array}$ & $\begin{array}{l}\text { SWSA 5, Facil.3047, } \\
\text { Facil.7920, Facil.7930 }\end{array}$ & 1 \\
\hline Bldg. 7920 & 2 & cans & $\begin{array}{c}\text { Bldg. } 3525 \text {, Bldg. } \\
3019\end{array}$ & $\begin{array}{l}\text { SWSA 5, Facil.3047, } \\
\text { Facil.7920, Facil.7930 }\end{array}$ & 2 \\
\hline $\begin{array}{l}\text { SWSA } 5 \text { North: } \\
\text {-- Facility 7823A }\end{array}$ & 9 & cans & \multirow[t]{3}{*}{$\begin{array}{l}\text { Bldg. } 3525, \text { Bldg. } \\
3019\end{array}$} & \multirow[t]{3}{*}{$\begin{array}{l}\text { SWSA 5, Facil.3047, } \\
\text { Facil.7920, Facil.7930 }\end{array}$} & \multirow[t]{3}{*}{90} \\
\hline - Facility 7827 & 67 & cans & & & \\
\hline - Facility 7829 & 14 & cans & & & \\
\hline \multicolumn{6}{|c|}{$\begin{array}{l}\text { 2542 shipments }=62 \text { currently stored fuel elements }+480 \text { fuel elements generated at } 1 / \text { month for the next } 40 \text { years. } \\
\text { n/a }=\text { not applicable } \\
\text { Sources: DOE } 1995 \mathrm{c} \text {, Appendix F; Klein 1995; J. Muecke, Research Reactors Division, ORNL, D. W. Turner, Waste Management and } \\
\text { Remedial Action Division, ORNL, and Laura Hofman, H\&R Associates, Oak Ridge, Tenn., personal communication to M. L. Socolof, } \\
\text { Energy Division, ORNL, Oak Ridge, Tenn., June, 1995. }\end{array}$} \\
\hline
\end{tabular}




\section{EXISTING ENVIRONMENT}

\subsection{NATURAL FEATURES}

This section briefly describe; the natural features of the ORR and then provides a description of the natural features of Melton Valley. Additional details on the proposed and alternative sites for the dry cask storage facility are also provided.

\subsubsection{Oak Ridge Reservation}

The DOE-owned ORR is located in Oak Ridge, Tennessee, approximately 25 miles west of Knoxville. The ORR consisis of 14,245 ha (35,200 acres) in a rural area bounded by the Clinch River on its eastern, southern, and western borders (Fig. 1.1). It is topographically characterized by valleys and ridges.

Abundant precipitation is the driving mechanism of the hydrologic system. The surface water hydrology on the ORR is characterized by a small network of streams that are tributaries to the Clinch River. The Clinch River is the primary source of water for the ORR and the City of Oak Ridge. The water intake is upstream of the ORR.

Groundwater in the area supplies water to rural residents, industries, and public water utilities, as well as sustaining base flow in streams and rivers. The properties of groundwater on the ORR are highly dependant on the geology of the area. The geologic units through and upon which the groundwater passes affect its flow and quality (Chance 1991).

Wetland areas within ORR consist mostly of small, swampy areas generally less than $9 \mathrm{~m}$ (30 ft) wide located within and around major drainage basins (Chance 1991). Wetlands are found in stream drainages and along Melton Hill Lake and Watts Bar Reservoir (near K-25, Fig. 1.1) (Cunningham and Pounds 1.991).

The dominant plant association on ORR is oak-hickory forest that is most widely distributed on ridges and dry slopes (Kitchings and Mann 1976, Mann et al. in press). Southern yellow pines (i.e., Virginia and shortleaf pines) are also common, especially in areas that were cleared and farmed before 1942. The most common understory trees throughout ORR are red maple, blackgum, and sourwood.

ORR provides habitat for a large number of animal species, including about 60 reptilian and amphibian species, more than 15:2 species of birds (including 32 species of waterfowl, wading birds, and shorebirds), and about 40 mammalian species (Mann et al. in press). Habitats supporting the greatest number of species are those dominated by hardwood forests and wetlands.

Suitable habitat for the federally listed threatened bald eagle exists on Melton Hill Lake, which borders ORR on the south, and eagles have recently been observed there. Also, a 


\section{3-2}

dead endangered gray bat was recently found at the Y-12 plant. No other federally listed threatened or endangered plant or animal species are known to occur on the ORR except for threatened peregrine falcons which are uncommon visitors.

Of the animals listed by the State of Tennessee as endangered or threatened (Hatcher 1994a), only the threatened osprey is known to occur regularly on the ORR. Other state endangered or threatened species of wildlife may occasionally visit the ORR, but suitable breeding habitat is not present (Kroodsma 1987). Wildlife species designated by the state as in need of management (Hatcher 1994b) that have been reported to occur on ORR are listed in Appendix A.

A number of plant species that are found on the ORR are candidates for federal listing or are listed by the State of Tennessee as endangered, threatened, or of special concern (Mann et al. in press). These species are listed in Appendix A.

A minimum of ten extensive archaeological reconnaissance surveys have been conducted on ORR with many documented by DOE (DOE 1983). Various archaeological sites exist on ORR, including Freels Cabin, an historic site, and the Jones House site. Freels Cabin is listed in the National Register of Historic Places pursuant to 36 CFR 60.4(d) and the Jones House is considered eligible for inclusion in the list. Neither of these sites or other archaeological sites identified on ORR are on either of the proposed sites for the dry cask storage facility.

\subsubsection{Melton Valley}

Melton Valley is an area within ORR where several designated waste management areas are located, including solid waste storage areas (SWSAs) 5, 6, and 7 (Fig. 2.1). The following sections describe the natural features of Melton Valley.

\subsubsection{Geology and soils}

Topography in and around Melton Valley is typical of that in the northwestern portion of the Valley and Ridge Province of East Tennessee. The valley is about $2 \mathrm{~km}$ (1.2 miles) wide and trends northeast/southwest. Haw Ridge lies about $1 \mathrm{~km}(0.6 \mathrm{miles})$ northwest of Melton Valley with crest elevations of approximately $305 \mathrm{~m}(1000 \mathrm{ft})$. Melton Hill, with a high crest of $413 \mathrm{~m}$ (1356 ft) on Copper Ridge, is located about $1 \mathrm{~km}$ (0.6 miles) southeast of the axis of Melton Valley. The lowest topography in the vicinity of the Melton Valley is at the mouth of White Oak Creek at its confluence with the Clinch River arm of Watts Bar Reservoir [normal pool elevation $226 \mathrm{~m}$ (742 ft)] (McCold et al. 1992).

The Conasauga Group, the bedrock underlying Melton Valley, is about $520 \mathrm{~m}(1700 \mathrm{ft})$ thick and is divided into the Pumpkin Valley Shale, Rutledge Limestone, Rogersville Shale, Maryville Limestone, Nolichucky Shale, and Maynardville Limestone (Fig. 3.1). As the 


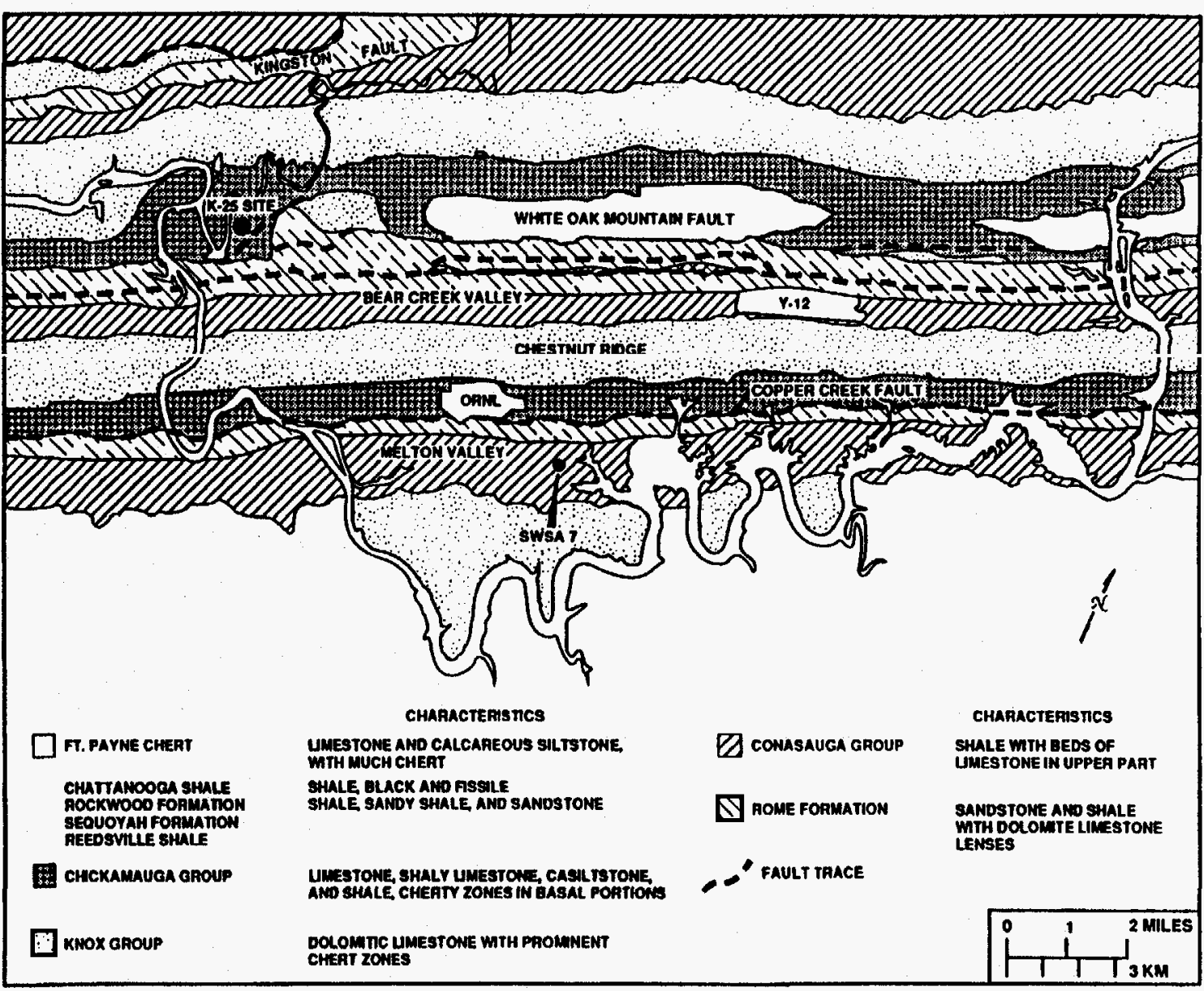

Fig. 3.1. Generalized geologic map of the Oak Ridge, Tennessee area 
names imply, these formations consist of nearly alternating limestone- and shale-dominated lithologies that outcrop in an alternating, banded pattern.

Structural features within Melton Valley are related to past motion along the Copper Creek Fault, a regionally major noncapable (i.e., inactive) thrust fault that strikes $\mathrm{N} 50^{\circ} \mathrm{E}$ to $\mathrm{N} 60^{\circ} \mathrm{E}$ and dips to the southeast at generally a shallow angle $\left(0-25^{\circ}\right)$ (Fig. 3.1). The Copper Creek Fault outcrops on the northwest slope of Haw Ridge about $1 \mathrm{~km}(0.6$ miles) northwest of SWSA 7 and underlies SWSA 7 at a depth of about $250 \mathrm{~m}(800 \mathrm{ft})$ below the land surface. There are no active faults in the Appalachian Basin within $320 \mathrm{~km}$ (200 miles) of SWSA 7 (NRC 1983, as referenced in McCold et al. 1992). An extensive study of ORR has been conducted to determine facility earthquake design criteria (McCold et al. 1992). Current earthquake design criteria are based on peak ground acceleration. Design peak ground accelerations for low-, moderate-, and high-hazard facilities on ORR are $0.15 \mathrm{~g}, 0.19 \mathrm{~g}$, and $0.32 \mathrm{~g}$ respectively. These peak ground accelerations corresponded to annual probabilities of exceeding these values of $2 \times 10^{-3}, 1 \times 10^{-3}$, and $2 \times 10^{-4}$, respectively (Kennedy et al. 1990).

In Melton Valley, geologic strike averages about $\mathrm{N}^{\circ} 5^{\circ} \mathrm{E}$, and the dip of the rock units is highly variable because of the highly deformed character of the Conasauga Group. Fractures associated with such intense geological deformation have been shown to be the primary pathway of groundwater movement on ORR.

Rock in the SWSA 7 area of Melton Valley weathers to a clayey residual soil derived from the underlying calcareous clay shale and interbedded limestone. Soil development on the Conasauga Group is generally thin [ $<1 \mathrm{~m}(3 \mathrm{ft})]$, and residual soils grade into a zone of saprolite (i.e., disintegrated rock in original location) (Rothschild et al. 1984b). A thin blanket of organic-rich topsoil overlies the residual soils. The boundaries between horizons (i.e., soils, saprolite, and bedrock) are gradational (Rothschild et al. 1984b). In general, the upland soils are well to moderately well drained, whereas soils in the lower zones may be poorly drained.

The only prime agricultural soil in the vicinity of Melton Valley is Pope soil (see Appendix B). This bottomland soil type occurs in areas less than $30 \mathrm{~m}$ (100 ft) wide adjacent to stream drainages in SWSA 7. Because of the small size of these areas, they would be of negligible agricultural use.

Beginning in 1994, a radiological survey was conducted at SWSA 7 to determine if the soil was radiologically contaminated and if so, to what degree. Random sampling was conducted in areas proposed for construction of solid low-level waste storage facilities. Fortytwo 3-m $\times 3-\mathrm{m}(10-\mathrm{ft} \times 10-\mathrm{ft})$ plots were sampled for gamma and beta radiation. The results of the survey determined that there were no areas of gamma radiation above background.

However, beta particles were found in all but four of the plots. The particles were found to be strontium-90 titanate $\left({ }^{90} \mathrm{SrTiO}_{3}\right)$, an insoluble form of ${ }^{90} \mathrm{Sr}$. Fifteen-cm (6-in.) depth profiles were conducted at four sampling plots. Contamination was found below the surface but began 
to taper off before $15 \mathrm{~cm}$ (6 in.). The number of particles per plot and disintegrations per minute (dpm) of beta radioactivity were recorded. The minimum, maximum, mean, and median number of contaminated parlicles per plot and activities per particle are presented in Table 3.1.

A sample was also taken at the alternative dry cask storage facility site location, near SWSA 5, which is where ${ }^{90} \mathrm{SrTiO}_{3}$ was historically taken for disposal. ${ }^{90} \mathrm{SrTiO}_{3}$ was found in higher concentrations at that one plo: than in SWSA 7. In a $0.3-\mathrm{m} \times 1.5-\mathrm{m}(1-\mathrm{ft} \times 5-\mathrm{ft})$ plot, approximately 25 particles were found at the surface, and a total of 85 particles were found in the same area to a depth of $15 \mathrm{~cm}(6 \mathrm{in}$.). The mean activity was $1098 \mathrm{dpm}$ per particle. Although there is no statistical support for making conclusions based on one plot, this information gives an indication that the SWSA 5 area may have more contamination than SWSA 7. Furthermore, it is logical to assume that the contamination would be greater in SWSA 5 since the material was disposed of in that area.

Table 3.1. Strontium titanatie soil contamination in Solid Waste Storage Area 7

\begin{tabular}{lccc}
\hline \multirow{2}{*}{$\begin{array}{c}\text { No. of contaminated particles per plot } \\
\text { (surface only) }\end{array}$} & \multicolumn{2}{c}{ Activity per particle (per plot) } \\
\cline { 2 - 4 } & 0 & $\begin{array}{c}\text { disintegrations } \\
\text { per minute (dpm) }\end{array}$ & $\mathrm{Bq}(\mathrm{Ci})^{\mathrm{a}}$ \\
\hline $\min$ & 56 & 261 & $4.4\left(1.2 \times 10^{-10}\right)$ \\
$\max$ & 12 & 9582 & $160\left(4.3 \times 10^{-9}\right)$ \\
mean & 6 & 1192 & $20\left(5.4 \times 10^{-10}\right)$ \\
median & 0 & 1091 & $18\left(4.9 \times 10^{-10}\right)$ \\
\hline
\end{tabular}

One dpm $=0.0167 \mathrm{~Bq} ; 1 \mathrm{~Bq}=2.7 \times 10^{-11} \mathrm{Ci}$.

Under the provisions of ORNL/M-116/R1 (ORNL 1988), the contaminated soils are listed as Category 2 soils. This categrory allows the excavated soil to be used as backfill, provided the area is not intended for continuous human occupation, but requires that the contaminated backfill be covered with $0.3 \mathrm{~m}$ ( $1 \mathrm{ft})$ of clean, uncontaminated soil.

\subsubsection{Groundwater hydrology}

Groundwater movement in the Melton Valley Conasauga Group of rocks has been extensively investigated (McCold et al. 1992; Rothschild et al. 1984a). The current understanding of Melton Valley is that this area is a groundwater discharge area; recharge of the groundwater in the Conasauga Group occurs at Haw Ridge (Figs. 3.1 and 3.2). The factors controlling fluid movement within the Conasauga Group vary with depth (Webster 1976, as 


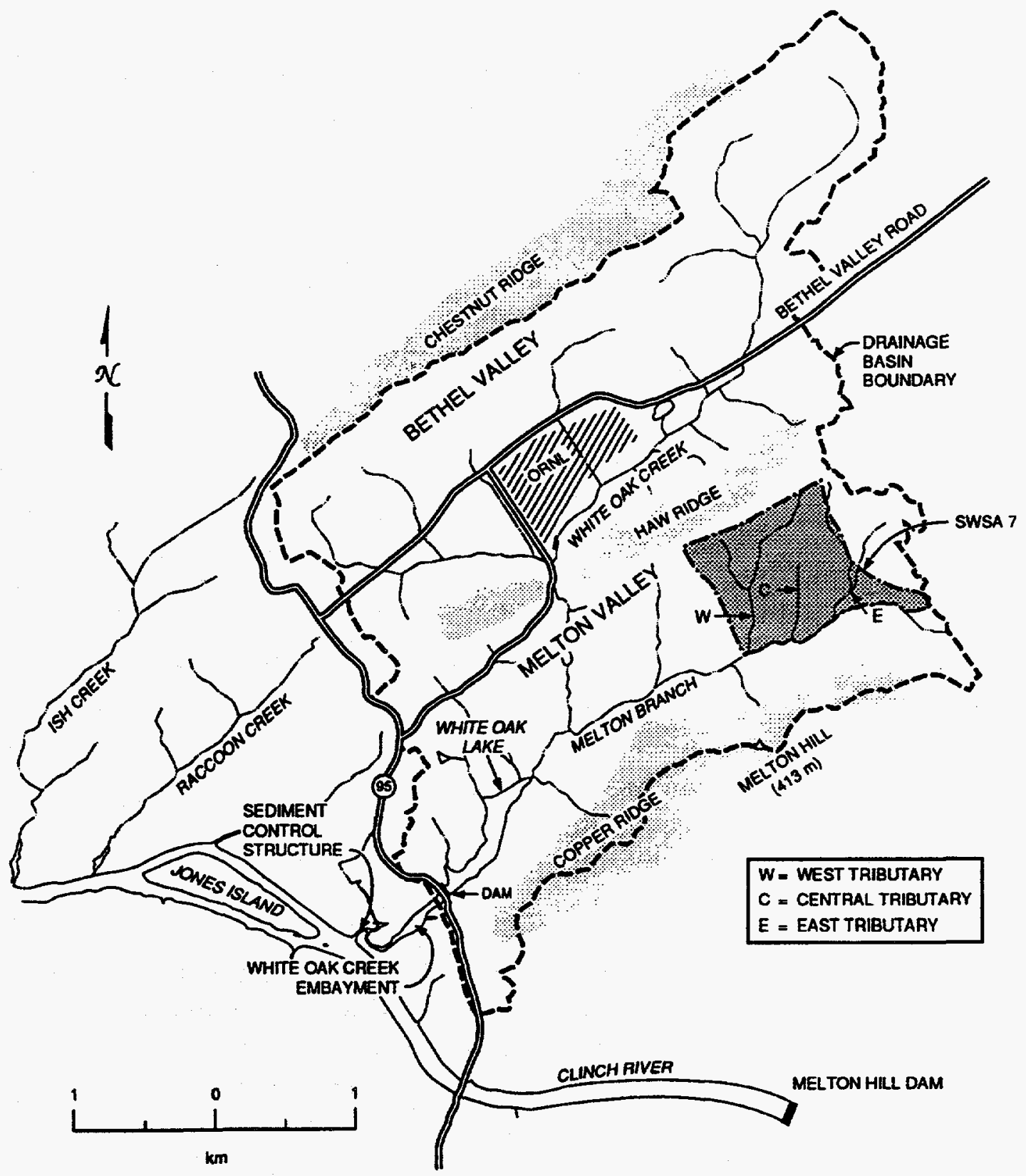

Fig. 3.2. White Oak Creek watershed. 
referenced in McCold et al. 1992). In the uppermost portion of the saturated zone, the slope of the water table (areal hydraulic gradient) is the primary factor controlling movement. With increasing depth, there is a change in control from the areal hydraulic gradient to control by local hydraulic gradients within more permeable zones in the rock (Webster 1976, as referenced in McCold et al. 1992).

\subsubsection{Surface water}

The majority of Melton Valley is drained in a southwesterly direction by the White Oak Creek watershed which drains an area of $16.4 \mathrm{~km}^{2}\left(6.37 \mathrm{mile}^{2}\right)$ (Fig. 3.2). The headwaters of White Oak Creek form along the crest of Chestnut Ridge at elevation $372 \mathrm{~m} \mathrm{(1220} \mathrm{ft),}$ dropping to an elevation of $226 \mathrm{~m}$ ( $742 \mathrm{ft}$ ) at its mouth where it joins the Clinch River downstream of Melton Hill Dam.

Melton Branch, the primary tributary of White Oak Creek, joins the main stem at White Oak Creek Mile $1.55(\mathrm{Km} 2.49)$ and has a drainage area of $3.83 \mathrm{~km}^{2}\left(1.48 \mathrm{mile}^{2}\right)$ above the confluence. The headwaters of Melton Branch form along Haw Ridge. Flow occurs in Melton Branch during much of the fall, winter, and spring months; however, during the summer months, there are periods of no flow (Loar et al. 1988 and 1992).

Surface runoff in Melton Valley discharges directly into Melton Branch via several small tributaries. Rapid runoff is promoted by the clayey, poorly drained, relatively impervious soils characteristic of East Tennessee. Approximately $30 \%$ (up to $85 \%$ on steep slopes) of the incident rain falling or unpaved, grassy surfaces flows overland into Melton Branch and associated tributaries (van der Leeden et al. 1991).

Liquid releases from ORNL enter the White Oak Creek watershed. The water quality of White Oak Creek and Melton Branch is monitored just upstream of their confluence at locations designated as NPDES pernitted discharge points. White Oak Creek was dammed to form White Oak Lake. White Oak lake serves as a settling basin to inhibit the off-site dispersion of radionuclides and chenical pollutants discharged from White Oak Creek by ORNL facilities. The White Oak Cleek Embayment sediment control structure, located west of the White Oak Lake Dam at the confluence of the Clinch River and White Oak Creek (Fig. 3.2), prevents further sediment transport out of White Oak Creek. Further information on radiological and nonradiological corstituent concentrations measured in the White Oak Creek watershed is available in Environmental Monitoring and Surveillance on the Oak Ridge Reservation: 1993 Data (Kornegay et al. 1994a). Analytical data for temperature, pH, specific conductance, major and minor dissolved constituents, gross alpha activity, gross beta activity, tritium, and volatile organic compounds for surface waters of the eastern end of Melton Valley from December 1987 to September 1988 are reported in Appendix D of Walker et al. (1988). 
Melton Branch and White Oak Creek do not serve as municipal or industrial water supplies. They are not suitable for contact recreation, and fishing is prohibited in them. The entire White Oak Creek watershed, including Melton Branch, is located within the confines of ORR. Access to this DOE-fenced area is restricted and not open to the public.

\subsubsection{Aquatic ecology}

Extensive studies of Melton Branch and White Oak Creek that were conducted under the ORNL Biological Monitoring and Abatement Program included instream ecological monitoring, studies of the periphyton communities, toxicity testing, radioecological studies, and studies of bioaccumulation of nonradiological contaminants. Results of the studies for 1986 through 1990 were reported in a series of annual reports (Loar et al. 1987, 1988, 1989, 1990, and 1991). Except during drier than normal months, there is sufficient flow in Melton Branch to allow the maintenance of a relatively diverse benthic macroinvertebrate community and a small fish community (Ryon 1988; Smith 1988a, 1992). Beaver dams are present at several places in the White Oak Creek watershed (Rosensteel 1995b).

The most recent fish surveys in lower Melton Branch [0.6 km (0.4 miles) above its confluence with White Oak Creek] found creek chubs, blacknose dace, and redbreast sunfish (Loar et al. 1991). The densities and standing crops of fish in lower Melton Branch are comparable with values from other small headwater streams in the area. Samples in uppermost Melton Branch [Melton Branch km 1.4 and 2.1 (miles 0.86 and 1.30)] found only creek chubs and blacknose dace. A weir on Melton Branch upstream of $\mathrm{km} 2.1$ (mile 1.3) serves as a barrier to movement of fish further upstream.

Most of the benthic macroinvertebrate taxa sampled in Melton Branch are typical of either moderately distributed or relatively undisturbed streams on ORR (Smith 1988a, 1988b; Smith and Ryon 1989). The relative abundance and biomass of disturbance-intolerant species of benthic insects [Plecoptera (stoneflies) and Ephemetoptera (mayflies)] in upper Melton Branch $\mathrm{km} 2.1$ (mile 1.30) were greater than the composition of the downstream sampling sites at $\mathrm{km} 1.2$ and 0.6 (miles 0.75 and 0.37 ) indicating that the upstream reaches are relatively undisturbed (Smith 1992).

\subsubsection{Terrestrial ecology/land use}

Meiton Valley contains a variety of ecosystems from those that are greatly disturbed to some that are relatively undisturbed. Where the valley has been heavily disturbed, the current vegetation cover is primarily grass and herbaceous plants. Vegetation of the rest of the valley is typical of forests found throughout ORR (Cunningham et al. 1988). Relatively undisturbed second-growth forests of mixed oak-hickory occur on the ridges and dry slopes, while pine and 
pine-hardwood on the lower slopes and valleys are typical of abandoned, eroded farmland on the ORR.

Wildlife in Melton Valley is also typical of ORR (Kroodsma 1985). Wildlife representative of that which occurs in the valley includes the rat snake, black racer, red-eyed vireo, scarlet tanager, red-tailed and red-shouldered hawks, yellow-billed cuckoo, coyote, deer mouse, gray squirrel, flying squirrel, and white-tailed deer.

No federally listed or proposed endangered or threatened plant or animal species or designated or proposed critical habitats are known to regularly occur in Melton Valley [consultation with the Fish and Wild life Service (FWS) is documented in Appendix B], but the threatened bald eagle and peregrine falcon are uncommon visitors to the vicinity.

While some state listed endangered or threatened species of wildlife (Hatcher 1994a) may occasionally visit the vicinity, no suitable breeding habitat is present, and no such animal species are known to regularly occur there (Kroodsma 1987). Of species listed by the state as in need of management (Hatcher 1994b), the southeastern shrew, Cooper's hawk, sharpshinned hawk, and yellow-bellied sapsucker are known to be present in Melton Valley. Other animal species listed by the state as in need of management that may be found in wetlands in Melton Valley are the northern harrier, the little blue heron, and the great egret (Mitchell 1995).

Some plants listed by the state as threatened or endangered are known to occur in Melton Valley. Pink lady's slipper, a species endangered in Tennessee due to commercial exploitation, and ginseng, a species listed by the state as threatened, grow in the valley. A small population of the state-listed threatened Canada lily grows in one wetland area. River bulrush and lesser lady's tresses, species listed by the state as of special concern, have also been reported from Melton Valley (Awl 1995).

A wetlands survey has been done for most of Melton Valley (Fig. 3.3). Forested, scrub-shrub, and emergent wetlands occur in seep and spring areas in the Melton Branch, White Oak Creek, and tributary bottomlands. Wetlands range in size from approximately 0.0031 ha (0.0077 acres) to almost $10 \mathrm{ha}$ (24.7 acres).

\subsubsection{Historic and archaeological resources}

No historic or archeological sites identified on ORR are found on the proposed or alternative dry cask storage facility sites (discussed in Sect. 3.1.1).

\subsubsection{Proposed Dry Cask Facility Locations}

An Energy Systems-led site selection committee reviewed six sites in Melton Valley as possible locations for the dry cask storage facility. Two sites, a preferred site and an alternate site (Fig. 2.2), were identified as the best sites on the basis of health and safety, functional, 


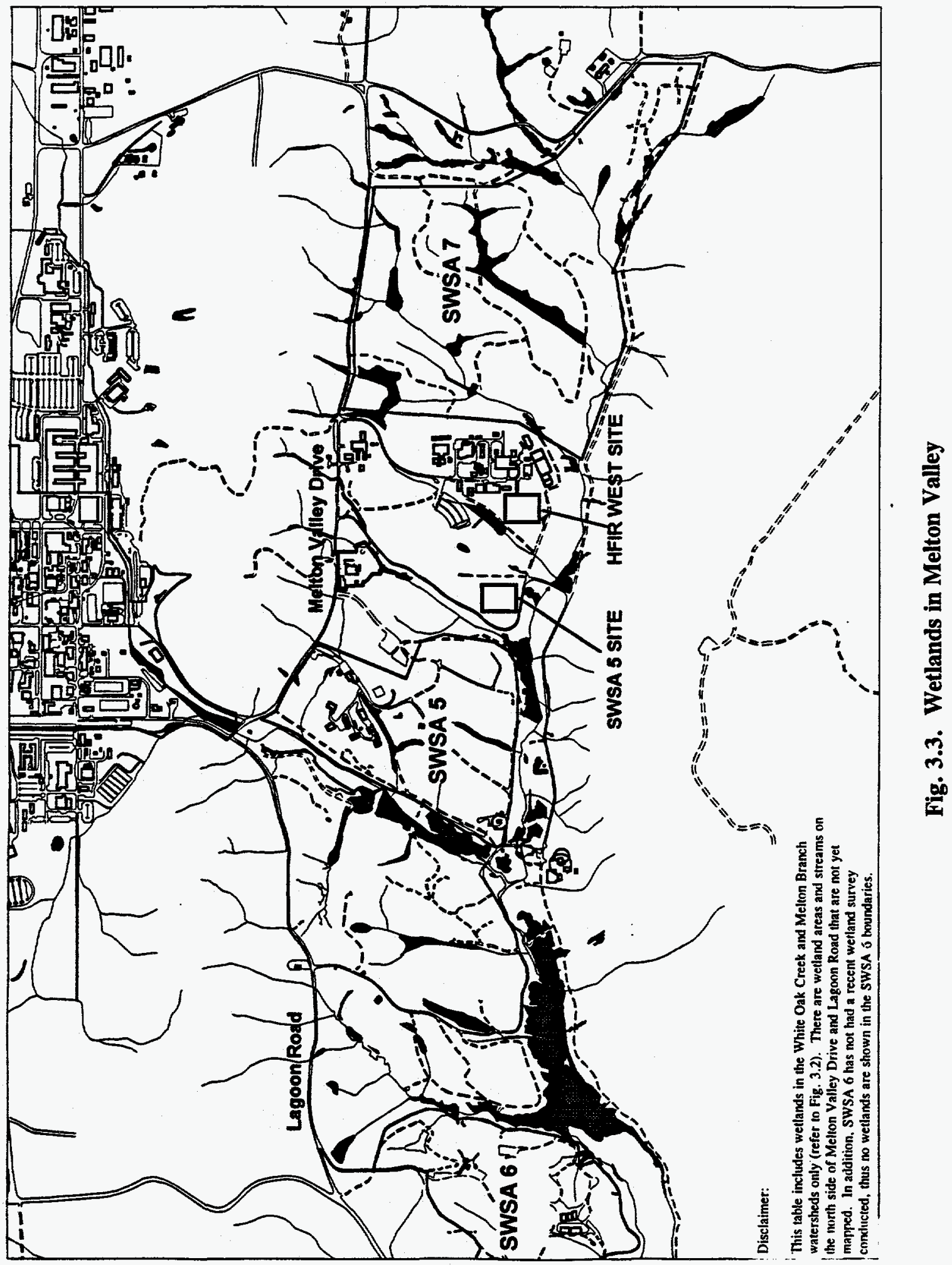


environmental, and programmatic criteria. The affected environment of those two sites is described below.

\subsubsection{Preferred location}

The preferred site is located to the south and west of the HFIR and is referred to as the HFIR West Site (Fig. 2.2). Twenty-one soil borings were drilled on and near the site in 1991 as part of a geotechnical study for a jroposed HFIR maintenance facility (ERCE 1991). This exploratory program revealed that subsurface materials at the site consist of a thin $[<15 \mathrm{~cm}$ $(0.5 \mathrm{ft})]$ veneer of topsoil, underlain by fill, residual soil/saprolite, and shale bedrock. The fill

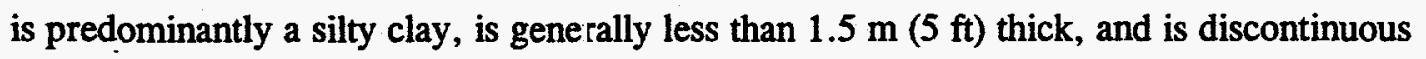
across the site. The underlying residual soil is mottled yellowish-tan to yellowish-brown to dark brown and grades from silty clay to clayey silt to weathered shale (saprolite). Except for the uppermost 0.9 to $1.5 \mathrm{~m}$ ( 3 to $5 \mathrm{ft}$ ), the residual soil consists of saprolite which retains much of the structure (i.e., fractures and bidding planes) of the parent bedrock.

Bedrock underlying the site consists of the Nolichucky Shale of the Cambrian Conasauga Group. The unweathered Nolichucky consists of olive green and purple shale with occasional lenses and thin interbeds of limestone.

Depths to groundwater ranged from 3.9 to $7.0 \mathrm{~m}(12.7$ to $22.9 \mathrm{ft})$ below ground surface [ $241 \mathrm{~m}(790.6 \mathrm{ft})$ mean sea level to $244.4 \mathrm{~m}(801.7 \mathrm{ft})$ mean sea level elevation] during measurements which were taken shortly after the borings were drilled. These measurements should be considered to represent maximum depths to groundwater, since water levels may not have stabilized in the boreholes after drilling.

Part of the site has been cleared and is used as a 45-50 m (148 - $164 \mathrm{ft})$ wide utility line corridor which has been reseeded with grasses (Rosensteel 1995a). The remainder of the site is a second-growth forest dominated by Virginia pine, red oak, and poplar, and is typical in vegetation and wildlife of abandoned farmland on ORR (Cunningham et al. 1988).

The site is bounded on the sciuth by a light-use, graveled dead-end road. On the upslope side of the road are two ponded seeps that are wetlands (Rosensteel 1995a). The total area of these two ponded seeps is approximately 0.02 hectares $(<0.05$ acres). The primary ecological function of these particular ponds is probably as habitat for aquatic and semi-aquatic species. Water insects, tadpoles, and frogs were observed in and around the ponds. The project would be designed so as to aroid those areas.

The area between the preferred and alternative sites was also surveyed for wetlands (Rosensteel 1995a). In addition to the utility line corridor mentioned above, two headwater streams that are tributaries to Meltor Branch cross this area. Wetlands are found in both tributary stream drainages. 
A small tributary of Melton Branch runs to the west of the site. Melton Branch itself runs south of the site on the other side of the gravel road. In this part of the valley, it is a perennial stream, probably due to input of water from the HFIR.

\subsubsection{Alternative location}

The alternative location is southwest of the HFIR near the curve in Melton Valley Circle Drive. The site is also south and east of SWSA 5 and is referred to as the SWSA 5 Site (Fig. 2.2). A pipeline for the Melton Valley Storage Tank - Capacity Increase Project is planned to run just east of this site.

Although no geological or groundwater investigations have been performed on this site, conditions are expected to be similar to undisturbed areas in the southeastern portion of SWSA 5, which is located to the west of the site on the other side of the Melton Branch Tributary. Extensive geological and groundwater investigations have been done in SWSA 5 for the Waste Area Grouping 5 Remedial Investigation (BNI 1994). Based on these investigations, soils at the alternative location should be similar to those at the preferred location, consisting of a thin veneer of topsoil underlain by a residual soil layer approximately 0.9 to $1.5 \mathrm{~m}$ (3 to $5 \mathrm{ft}$ ) thick, which are in turn underlain by saprolite (i.e., highly weathered bedrock). Bedrock underlying the site consists of the upper Maryville Limestone of the Cambrian Conasauga Group. The unweathered upper Maryville consists of limestone interbedded with shale.

Based on water level measurements in wells in the southeastern portion of SWSA 5, groundwater at the alternative location should be encountered from 1 to $6 \mathrm{~m}$ ( 3 to $20 \mathrm{ft}$ ) below ground surface. Groundwater depths should be greater in the topographically higher portions of the site and during the dry part of the year (i.e., from April through November).

The alternative site is dominated by Virginia pine, tulip poplar, sweetgum, oak saplings, flowering dogwood, Japanese honeysuckle, and microstegium. A wetlands survey of the site found no springs, seeps, streams, or other wetlands (Rosensteel 1995a). This area is also the location of the ${ }^{90} \mathrm{SrTiO}_{3}$ sampling conducted near SWSA 5 (Sect. 3.1.2.1).

\subsection{BACKGROUND RADIATION DOSE}

The background radiation doses to the public and occupational workers at ORR are provided in this section. This information is used to compare impacts from proposed activities to existing conditions.

\subsubsection{Public Radiation Dose}

The average annual radiological effective dose equivalent (EDE) to an individual residing in the United States is approximately $3.6 \mathrm{mSv} /$ year (360 mrem/year) (NCRP 1987). 
The sources and approximate doses of this total exposure are presented in Table 3.2. External radiation exposure rates from background sources have been measured in Tennessee. The measured rates are equivalent to an average EDE of $0.42 \mathrm{mSv} /$ year ( $42 \mathrm{mrem} /$ year), ranging between 0.19 and $0.72 \mathrm{mSv} /$ year (19 and $72 \mathrm{mrem} /$ year) (Myrick et al. 1981). A typical annual EDE to the maximally exposed individual due to external radiation from ORR is about $0.01 \mathrm{mSv}$ ( $1 \mathrm{mrem}$ ), which is about $2.4 \%$ of the natural external radiation background EDE to an average Tennessee resident. Airtiorne emissions from ORR are expected to contribute to internal (e.g., inhalation) and externil off-site radiation exposures. Table 3.3 shows the 1993 EDEs from ORR and ORNL airborne emissions to the hypothetically maximally exposed individual and the collective population within $80 \mathrm{~km}$ (50 miles). The collective population EDE from ORR airborne emissions, of about 0.26 person-Sv (26 person-rem), represents approximately $0.01 \%$ of the $2.6 \times 10^{3}$ person-Sv $\left(2.6 \times 10^{5}\right.$ person-rem) the surrounding population would receive from all sources of natural radiation (i.e., radon and other natural sources) (Kornegay et al. 1994b). Table 3.3 also shows the EDE from all exposure pathways from gaseous and liquid releases to the maximally exposed individual. DOE Order 5400.5, "Radiation Protection of the Public and the Environment," limits the EDE that an off-site individual may receive from all expcsure pathways and all radionuclides released from ORR during 1 year to no more than $1.0 \mathrm{mSv}$ (100 mrem). The 1993 exposures are $3 \%$ of this DOE limit.

\subsubsection{Occupational Radiation Dose}

The annual average EDE to radiation workers in the United States (e.g., medicine, industry, nuclear fuel cycle, governinent) is approximately $2.2 \mathrm{mSv} /$ year ( $220 \mathrm{mrem} / \mathrm{year}$ ) (NCRP 1987). Limited data have also been collected on occupational exposures to workers at low-level waste disposal facilities. In 1989, a total of 925 individuals were monitored, 119 of whom had measurable exposures. Their collective dose was approximately 0.35 person-Sv ( 35 person-rem), and the average dose to those with measurable exposures was $3 \mathrm{mSv}$ ( $300 \mathrm{mrem}$ ). The individual exposures ranged from nonmeasurable to approximately $0.02 \mathrm{~Sv}$ ( $2 \mathrm{rem}$ ) (NRC 1992).

In 1991, the ORNL collective dose to 57 waste operations radiation workers (in the Waste Management and Remedial Action Division) was 5.61 person-mSv (561 person-mrem). Fourteen of those workers had measurable exposures and their average exposure was $0.40 \mathrm{mSv}$ (40 mrem). The maximum dose equivalent received by an individual worker was $1.40 \mathrm{mSv}$ (140 mrem) and the minimum was C mSv (0 mrem) (Setaro 1995). Work crews from ORNL's Plant and Equipment Division are assigned to the waste operations group on a rotating basis. When Plant and Equipment personnel are not assigned to the waste operations group, they work within other areas of ORNL and are subject to radiation exposure at those areas; therefore, their average doses are not received solely from waste operations. The dose to Plant 
Table 3.2. United States individual background radiation effective dose equivalents (EDEs)

\begin{tabular}{lc}
\hline Radiation source & $\begin{array}{c}\text { Annual EDE } \\
\text { [mSv/year (mrem/year)] }\end{array}$ \\
\hline $\begin{array}{l}\text { radon and its progeny } \\
\text { other natural sources } \\
\text { (cosmic, terrestrial, and internal radiation) }\end{array}$ & $2.0(200)$ \\
$\begin{array}{l}\text { medical exposures } \\
\text { (x-rays and nuclear medicine) }\end{array}$ & $1.0(100)$ \\
$\begin{array}{l}\text { consumer products } \\
\text { other sources } \\
\text { (occupational, nuclear fuel cycle, fallout) }\end{array}$ & $0.5(50)$ \\
\hline Total & $0.09(9)$ \\
Source: NCRP 1987 & $0.01(1)$ \\
\hline
\end{tabular}

Table 3.3. Annual radiation effective dose equivalents (EDEs) from ORR and ORNL

\begin{tabular}{lcc}
\hline & \multicolumn{2}{c}{ Annual EDE } \\
\cline { 2 - 3 } & $\begin{array}{c}\text { maximally exposed individual } \\
\text { [mSv/year (mrem/year)] }\end{array}$ & $\begin{array}{c}\text { population within } 80 \mathrm{~km} \text { (50 miles) } \\
\text { [person-Sv/year (person-rem/year)] }\end{array}$ \\
\hline \multirow{3}{*}{ ORR } & All exposure pathways (internal, external) from airborne emissions \\
ORNL & $0.014(1.4)$ & $0.26(26)$ \\
& $0.001(0.1)$ & $0.06(6)$ \\
ORR & All exposure pathways (internal, external) from all releases (gaseous, liquid) & not available \\
\hline
\end{tabular}

Approximately 880,000 persons

Source: Kornegay et al. $1994 \mathrm{~b}$

and Equipment workers handling specific waste or other materials cannot be established because of the rotating schedule of the workers.

DOE Order 5480.11, "Radiation Protection for Occupational Workers," establishes radiation protection standards and program requirements for DOE and DOE contractor operations with respect to the protection of workers from ionizing radiation. DOE's limiting value for a worker's radiation dose is $50 \mathrm{mSv} /$ year ( $5 \mathrm{rem} / \mathrm{year}$ ) (anmual EDE) from both internal and external sources received in any year for the whole body. The Energy Systems 
Radiation Control Manual (DOE/EH-0256T) sets an Energy Systems administrative control level of $15 \mathrm{mSv}(1.5 \mathrm{rem})$ per year for all activities. Exceeding this control level requires approval of the Laboratory Director and Energy Systems President. DOE also has a policy that requires exposures to be as low as reasonably achievable (ALARA). ORNL's 1995 ALARA control level goal is to keep individual occupational exposures below $6.5 \mathrm{mSv} /$ year ( $0.65 \mathrm{rem} / \mathrm{year}$ ). Permission from an ORNL division director is required if exposure is to exceed $6.5 \mathrm{mSv} /$ year $(0.65 \mathrm{rem} / \mathrm{year})$. The ORNL ALARA Steering Committee may approve individual exposures to exceed $6.5 \mathrm{~m} / \mathrm{Sv} / \mathrm{year}$ ( $0.65 \mathrm{rem} / \mathrm{year})$, but not to exceed the Energy Systems administrative control level of $15 \mathrm{mSv} /$ year ( $1.5 \mathrm{rem} /$ year). 


\section{ENVIRONMENTAL IMPACTS}

\subsection{CONSTRUCTION}

\subsubsection{Preferred Site}

\subsubsection{Water resources}

Construction of the dry cask storage facility at the preferred site would result in the clearing of 1.2 ha ( 3 acres), and the pouring of an undetermined size concrete pad to hold the storage casks. The remainder of the cleared area would be graveled to serve as a staging area while placing SNF into the storage casks.

Based on limited groundwater studies, the depth to the water table in the area of the preferred site ranges from approximately 3.7 to 7.0 meters (12 to 23 feet) below ground surface. Therefore, cut and fill operations and the installation of groundwater suppression

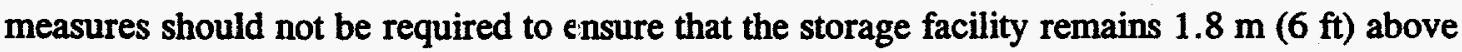
the water table (design criteria).

There are no surface waters located on the preferred site. However, construction activities could result in soil erosion and subsequent sedimentation in Melton Branch or its tributaries. Site clearing and gradings would be done using best available technology to minimize alteration of the existing surface water drainage pattern of the site. Also, use of sediment containment structures sucl 1 as silt fences would minimize impacts. Such mitigation measures would minimize the overall impacts on aquatic resources in Melton Branch from construction of the storage pad and would protect the diversity and density of aquatic life there.

\subsubsection{Ecological resources}

For the dry cask storage facility, 1.2 ha ( 3 acres) of pine forest and/or low growing herbaceous plants in the power line isorridor would be cleared. The total forest that would be cleared for this project is a very small fraction of the roughly 2300 ha (5600 acres) of pine forest on ORR. Even if the clearing occurred only in the pine forest, the cleared area would only be $\mathbf{0 . 0 5 \%}$ of the pine forest on ORR. Thus, only a small amount of natural vegetation on this site would be lost with a corresfondingly small amount of wildlife populations also lost. Areas disturbed during construction but not needed for the facility would be revegetated after construction is completed with native species following Executive Order 11987, "Exotic Organisms" and DOE 5400.1/AI-1 which restrict the introduction of exotic species into natural ecosystems on federally owned land. 
No federally listed threatened or endangered species of plants or animals or designated critical habitats are known to occur on or near the site. Also, no species listed by the state as threatened, endangered, or in need of management are known to regularly occur on the site. Therefore, none would be affected by construction.

To prevent wetlands disturbance, the facility would be sited north of the existing transmission line, and the boundaries of the wetlands south of the transmission line would be marked with flags before construction. A $15 \mathrm{~m}$ (50 ft) buffer around the wetland would be adequate to reduce the potential impacts to it. Because the proposed project would not involve construction activity within a wetland, no consultation is required with the U.S. Corps of Engineers regarding a Sect. 404 permit.

While the soils at the preferred site have not been sampled for contamination, the site would be monitored by Health Physics and Industrial Hygiene personnel during excavation in accordance with ORNL/M-116/R1 (ORNL 1988). Strontium titanate contamination as found in SWSA 7 and the alternative site soils may also be found at the preferred site. It is estimated that conditions that would result in $1 \mathrm{mSv} /$ year ( $100 \mathrm{mrem} /$ year) human environmental exposure would lead to dose rates to plants and animals of less than $1 \mathrm{mGy} /$ day ( $100 \mathrm{mrad} /$ day) (IAEA 1992). Irradiation of even the most sensitive species at chronic dose rates of $1 \mathrm{mGy} /$ day (100 mrad/day) or $10 \mathrm{mGy} /$ day (1000 mrad/day) would not affect terrestrial animal or plant populations, respectively. Because the potential exposures to ${ }^{90} \mathrm{Sr}$-contaminated surface soil in SWSA 7 and near SWSA 5 are well below these amounts (based on a conservative cumulative impact assessment in Sect. 4.4.8), risk to biota are assumed to be negligible.

\subsubsection{Health and safety}

All construction activities would be conducted in accordance with ORNL, Energy Systems, and DOE policies regarding protection of personnel and the environment. This includes procedures in the ORNL Environmental Protection Manual, the ORNL Safety Manual, the ORNL Health Physics Procedures Manual, and the ORNL Industrial Hygiene Manual. All activities would also be conducted in accordance with ALARA objectives. Health Physics and Industrial Hygiene personnel would monitor the site during any excavation activity in accordance with ORNL/M-116/R1 (ORNL 1988). This procedure includes requirements for protective clothing when contaminated soils are encountered. Although soils have not been sampled at the preferred site, a bounding analysis (assuming soil contamination) from several construction activities in Melton Valley is conducted in the cumulative impacts section (Sect. 4.4.8). That analysis found exposures to the contaminated soils from excavation to be nominal and of no health concern. 


\subsubsection{Alternative Site}

This section describes impacts to water and ecological resources. Impacts to human health and safety would be the same as for the preferred site.

\subsubsection{Water resources}

Based on data from groundvater level measurements in SWSA 5, directly to the west of the alternative site, the depth to the water table in the area of the alternative site should range from approximately 1 to $6 \mathrm{~m} \mathrm{(3} \mathrm{to} 20 \mathrm{ft}$ ) below ground surface. Therefore, cut and fill operations and/or the installation of groundwater control measures may be required to ensure

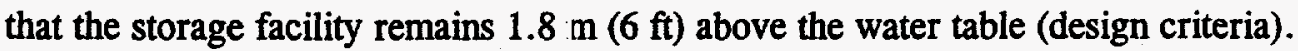
Construction of the dry cask storage facility at the alterative site would result in impacts and would use mitigation measures similar to those discussed above under the preferred site.

\subsubsection{Ecological resources}

If the dry cask storage facility were built at this site, 1.2 ha ( 3 acres) of second-growth forest would be cleared. Although having the facility at this site might result in slightly more forest clearing than for the preferrel site (because there is more second-growth forest), it would still be a minor change in land cover and would have minimal impacts on wildlife on ORR. There are no wetlands or threatened or endangered species or species in need of special management on or near this site.

Strontium titanate soil contamination was found in one sample plot taken on the site. Based on the conservative cumulative impact assessment (Sects. 4.4.6 and 4.4.8), the potential exposure from soil contamination found at this location is below concern to humans, and thus the risk to biota are assumed to be regligible (see Sect. 4.1.1.2).

\subsection{SNF NORMAL OPERATIION (HANDLING/STORAGE)}

\subsubsection{Water Resources}

The ORNL Active Sites Environmental Monitoring Program is involved with compliance to meet the monitoring requirements of DOE Order 5820.2A. In that capacity, elevated values of $\mathrm{pH}$ and gross beta activity have been observed during monitoring at the SWSA 6 Interim Waste Management Facility (IWMF), which consists of a large concrete pad topped with concrete vaults (Morrissey 1995). The $\mathrm{pH}$ of water running off of the concrete slab itself measures about 8.5, just below the NPDES upper limit of 9.0. However, when vaults are added to the pad, the additional concrete can cause the $\mathrm{pH}$ to exceed 9.0 at times. 
When that occurs, carbon dioxide is automatically bubbled through the water to bring it into compliance before it is discharged.

DOE Order 5400.5 establishes guidelines for radionuclide releases to the environment by DOE facilities. In order to detect releases of radioactivity from the vaults, the action level for gross beta activity for the IWMF was set at a very conservative value of $5 \mathrm{~Bq} / \mathrm{L}$ $\left(1.4 \times 10^{-10} \mathrm{Ci} / \mathrm{L}\right)$. However, that level is occasionally exceeded, due to the leaching of potassium-40 from the concrete (Morrissey 1995). This exceedance is not considered to be a problem by the ORNL Active Sites Environmental Monitoring Program, and no effort is needed to correct it.

When construction of the dry cask storage facility is complete, a concrete pad would hold concrete storage casks with a gravel area next to it for parking trucks during loading and unloading operations. The concrete pad would be sloped to collect water which would likely be checked to determine if it met the NPDES limits before being discharged. Any measures which exceed the NPDES levels (e.g., pH) would be corrected before the water is discharged. The action level for radioactivity for the dry cask facility would likely be set at a higher level than that for the IWMF based on the experience with leaching from the concrete at the IWMF (Valentine 1995). Compliance with the monitoring requirements of DOE Order 5820.2A could be facilitated by the ORNL Active Sites Environmental Monitoring Program.

The concrete pad could cause faster and greater runoff of storm water because there would be less natural ground surface to allow absorption and longer retention. A natural buffer between the concrete pad and Melton Branch would be more than $30 \mathrm{~m}$ ( $98 \mathrm{ft}$ ) which should be adequate to allow runoff to be slowed and absorbed before reaching the creek. This change would probably not affect the hydrology of the wetlands south of the preferred site since they are likely the result of the road south of them which blocks downslope drainage (Rosensteel 1995a).

\subsubsection{Ecological Resources}

Except for noise from trucks and equipment, operation of the dry cask storage facility would not be expected to have any impact on vegetation, wildife, or rare plants or animals. Noise from trucks carrying SNF to the site and equipment at the site might disturb wildlife. But this impact would be minimal because (1) the preferred site is near the HFIR complex and a road, both of which already produce noise and (2) the additional noise on the site would be infrequent. Similarly, noise impacts would be minimal at the alternative site since it is near a road and SWSA 5. 


\subsubsection{Health and Safety}

Operational activities includ» handling, repackaging, and storing SNF. The primary health hazard during operations would be the presence of radioactive material. In general, the potential human exposure pathways for radiation exposure include external radiation, inhalation of airborne radionuclides, ingestion ior direct contact with waterborne radionuclides, and ingestion of radionuclides in the food chain. Incident-free handling would only be expected to result in low dose rates of external ridiation exposure. At all times SNF would be contained in shielded containers to minimize personal external exposure. During transport, the SNF would be contained in shielded shipping casks; during storage, in shielded concrete storage casks; and during repackaging activities, in hot cells designed for remote manipulation of radioactive material.

Impacts on human health from operations are bounded by the PEIS analysis (DOE 1995c, Volume 1, Appendix F-ORR) and, therefore, not detailed here. The analysis is bounding because the PEIS assesses a large centralized facility for storage of all DOE SNF throughout the United States. Therefore, the PEIS-estimated exposures to the average SNF storage facility worker of approximately $0.40 \mathrm{mSv} /$ year $(40 \mathrm{mrem} / \mathrm{year})$ would be bounding for the currently proposed activities on ORR. This estimated exposure rate is the same as the average dose to ORNL waste operations workers described in Sect. 3.2.2. To ensure safe working conditions, all workers, including hot cell technicians, would be monitored to ensure that exposures do not exceed DOE's annual limit of $50 \mathrm{mSv}$ (5 rem) and to strive to keep exposures to ALARA levels. To meet ALARA goals, the maximum dose rate to operational personnel from the highest-activity SNF cannot exceed $0.025 \mathrm{mSv} / \mathrm{h}(2.5 \mathrm{mrem} / \mathrm{h})$.

Furthermore, as stated in Sect. 2.2.2.2, radiation exposure of operations personnel in the dry cask storage area would have to be in compliance with other applicable radiation protection regulations. The radiological alarm system and criticality monitoring system provided in the storage facility where special nucleaj material (e.g., plutonium) would be stored or handled would provide protection against radiological exposure and preclude a criticality event.

The off-site population dose within an $80-\mathrm{km}$ (50-mile) radius of ORR from SNF operations of the PEIS centralized fasility was estimated at 0.052 person-Sv/year (5.2 person-em/year) (DOE 1995c). This bounding exposure level is $20 \%$ of the current dose from airborne emissions from the OKR of 0.26 person-Sv/year (26 person-rem/year) (Sect. 3.2.1).

The PEIS analysis also estimated exposures and cancer fatalities to workers and the public from incident-free transportation. This PEIS analysis is also bounding because it assesses the large centralized facility and assumes greater on-site distances are travelled than would be under the proposed action in this analysis. Therefore, impacts from currently proposed SNF activities on ORR would be less than those calculated in the PEIS: $1.36 \times 10^{-4}$ occupational fatal cancers and $4.28 \times 10^{-6}$ public fatal cancers. To put these values in 
perspective, the DOE occupational limit of $50 \mathrm{mSv} / \mathrm{year}$ ( $5 \mathrm{rem} / \mathrm{year}$ ) would be associated with a cancer fatality risk of $2 \times 10^{-3}$, and the background individual annual exposure of 3.6 $\mathrm{mSv} /$ year ( $360 \mathrm{mrem} / \mathrm{year}$ ) to the general public would be associated with a cancer fatality risk of approximately $2 \times 10^{-4}$.

\subsection{ACCIDENTS}

\subsubsection{Construction}

Standard industrial accidents of the following types could be associated with construction of the proposed facility: (1) those routinely encountered and/or accepted by the public in everyday life, (2) those encountered in general industry that do not greatly affect a large number of people, or (3) those encountered in general industry and controlled through the application of recognized codes and safety standards [e.g., Occupational Safety and Health Administration (OSHA) standards)]. Workers would comply with the applicable DOE Order 5480.9, "Construction Safety and Health Program," and all applicable OSHA provisions.

In 1991, the U.S. construction industry reported 3 disabling injuries (including temporary disabilities, but excluding deaths) for every 100 workers. Most accidents in the construction industry result from overexertion, falls, or being struck by equipment (NSC 1992). Assuming the same injury rate at ORNL, less than one (0.3) injury would statistically be expected to occur in one year out of the approximately 10 construction workers. Standard industrial illness (e.g., skin disorders from exposure to chemical spills) in the construction industry occur at a rate of about 19 per 10,000 full-time workers (NSC 1992). No illness would statistically be expected based on national incidence rates. Nonetheless, to avoid exposure from potential spills of liquids (e.g., hydraulic fluid, lubricating oil, fuels, and ethylene glycol if construction equipment overturned), construction workers would be trained in implementing spill prevention, control containment, and cleanup measures. Personal protective equipment is generally not required for such cleanup.

Impacts to groundwater and/or surface water from unlikely accidental spills of hazardous construction liquids would be minimized by using approved rapid spill emergency response actions as described in the ORNL Spill Prevention, Control, Countermeasures, and Contingency Plan (September 1985). Such response actions would minimize the potential for transport of hazardous materials through soil and rock fractures into the groundwater. In addition, the rapid spill emergency response procedures would minimize impacts to surface water. Thus, potential impacts on aquatic resources from runoff, sediment transport, leaks, or spills from the facility should be minimal. Any soil contaminated by a spill of hazardous liquid, which would be unlikely, would be collected and disposed of at appropriate ORNL waste disposal facilities. 


\subsubsection{Operation}

The PEIS analyzed several accident scenarios. The accident scenario that could occur during operations of SNF operations at ORR and that would result in the greatest probable risk (risk times probability) to the maximally exposed off-site individual is a fuel assembly breach. This could occur from objects falling; on the assembly, cutting into the assembly, or dropping the assembly. For example, during repackaging, a fuel assembly could be cut. This type of accident is expected to occur much less frequently than $1.6 \times 10^{-1}$ per year (DOE 1995c, Volume 1, Appendix F-ORR, p. 3.5-63). The dose and associated cancer fatality risk to the highly conservative maximally exposed off-site individual for this type of accident was found to be $1.2 \times 10^{-4} \mathrm{~Sv}\left(1.2 \times 10^{-2} \mathrm{rem}\right)$ and $6 \times 10^{-6}$ cancer fatality risk, respectively. The associated probabalistic cancer fatality risk from a fuel assembly breach is $9.6 \times 10^{-7}$ (i.e., less than a one in a million chance of dying of cancer due to the accident) (DOE 1995c, Volume 1, Appendix F-ORR, p. 3.5-57 and -59).

The accident scenario that vould result in the greatest probable risk to workers is a dropped fuel cask. This scenario involves dropping and overturning a fuel cask in an existing storage pool (e.g., the HFIR pool). The probability of this accident is estimated to be less than $1 \times 10^{-4}$ per year (DOE 1995c, Volume 1, Appendix F-ORR, p. 3.5-63). The dose and associated cancer fatality risk to a worker for a dropped fuel cask was found to be $0.047 \mathrm{~Sv}$ $(4.7 \mathrm{rem})$ and $1.9 \times 10^{-3}$ cancer fatality risk, respectively. The associated probabalistic cancer fatality risk from a dropped fuel cask is $1.9 \times 10^{-7}$ (i.e., about a two in ten million chance of dying of cancer due to the accident) (DOE 1995c, Volume 1, Appendix F-ORR, p. 3.5-57 and $-59)$.

\subsection{CUMULATIVE IMPACTS}

DOE has proposed or approved the construction and operation of a number of waste management activities in Melton Valley through 1995 (Fig. 4.1). NEPA documentation has been completed or is being prepared for each of these proposed actions. The cumulative impacts from the implementation of these actions in Melton Valley are assessed in this section. The following is a listing and short clescription of these proposed projects, including the proposed action assessed in this document. No significant impacts were found for any of the projects that have approved EAs. 


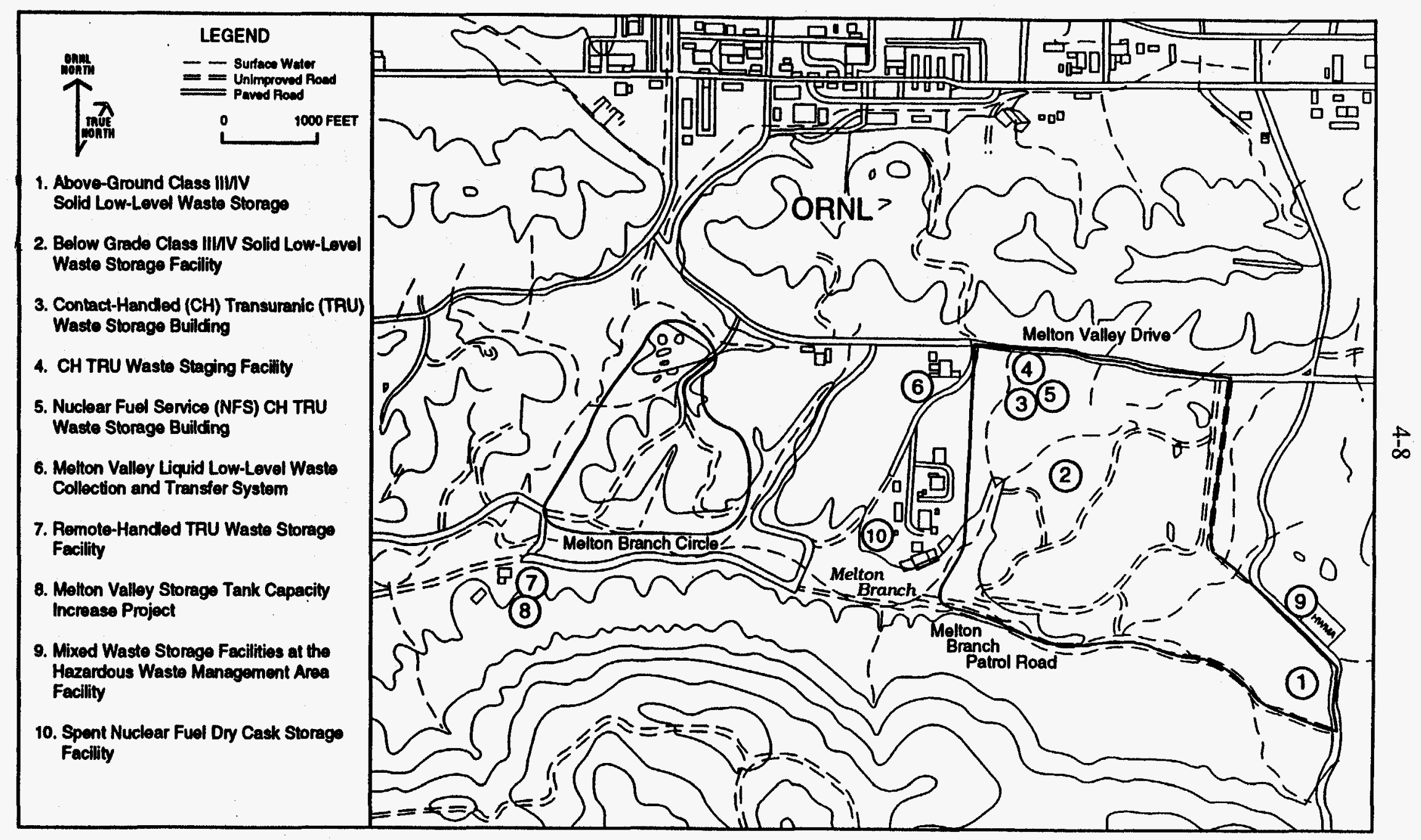

Fig. 4.1. Site locations for Oak Ridge National Laboratory's proposed waste management projects for Melton Valley through 1995. Some locations are preliminary sites for proposed facilities. 
- Class III/IV solid low-level waste (SLLW) storage facilities (sites 1 and 2 on Fig. 4.1)-The proposed facilities consist of one above-grade and four below-grade SLLW storage facilities to be: constructed and operated in SWSA 7. Construction of these facilities would result in clearing approximately 5.3 ha (13 acres) [1.6 ha ( 4 acres) for the above-grade facility and 3.6 ha $(9$ acres) for the four below-grade facilities]. Construction and operation of the below-grade facilities would occur consecutively as required ovir approximately 10 years.

- Contact-handled (CH) and remote-handled (RH) transuranic (TRU) waste storage buildings (sites 3, 4, and 7 cn Fig. 4.1)-Two $\mathrm{CH}$ TRU waste storage facilities and one RH TRU waste staging/storage facility have been approved for construction and operation in SWSA 7. Thes: metal buildings will store CH TRU and mixed CH TRU waste. Approximately $1.2 \mathrm{ha}$ ( 3 acres) will be cleared and leveled for this project. The RH TRU waste storage :acility will consist of one reinforced concrete bunker to store casks of RH TRU and IRH TRU mixed waste generated at ORNL. The building will be in Melton Valley, and approximately 0.4 ha ( 1 acre) will be cleared. All TRU facilities will be RCRA permitted. An approved EA (DOE 1995a) resulted in a finding of no significant impact.

- Nuclear Fuel Services CH ITRU storage building (site 5 on Fig. 4.1)-A metal building has been approved to store mixed waste being transported from the Nuclear Fuel Services facility in Erwin, Tennessee. This facility will be located in the northwest corner of SWSA 7. Approximately 1.2 ha ( 3 acres) will be cleared. The approved EA for this project (DOE 1992) resulted in a finding of no significant impact.

- Melton Valley liquid low-lerel waste (LLLW) collection and transfer system (site 6 on Fig. 4.1)-This project, covered by a NEPA categorical exclusion for on-going operations, is designed to upgrade existing underground LLLW transport lines from the Radiochemical Engineering (Center in Melton Valley to existing waste lines in the main ORNL complex located in Bethel Valley. The project also includes the construction of a monitoring and control station for collection of LLLW from Melton Valley facilities and the addition of an ion ex:hange system in the HFIR building for treatment of HFIR waste. Dewatered and dried spent ion exchange resins (Class II SLLW) would be stored as part of the Class III/IV above-grade inventory. Approximately 1.6 ha ( 4 acres) of land will be disturbed by construction associated with the upgrade.

- Melton Valley Storage Tank-Capacity Increase Project (MVST-CIP) (site 8 on Fig. 4.1)-This project includes construction and operation of eight LLLW storage tanks. These tanks are needed to inirease the capacity of ORNL's existing LLLW storage tanks. Approximately 2 ha ( 5 acres) will be cleared. The final EA for this project (DOE 1995b) resulted in a finding of no significant impact.

- Mixed waste storage facilities (site 9 on Fig. 4.1)-These facilities are proposed to expand the storage capacity of hazardous mixed waste storage facilities located just to the east of SWSA 7. Approximately 0.1 ha $(0.25$ acre $)$ of land will be affected by construction of proposed buildings. The final EA for this project (DOE 1994) resulted in a finding of no significant impact. 
- Spent nuclear fuel dry cask storage facility (site 10 on Fig. 4.1)-Construction and operation of this facility is contingent upon not being able to ship spent nuclear fuel out of state. If necessary, a concrete storage pad would be built on a 1.2-ha (3-acre) site just west of the HFIR. An EA is being prepared to address this project.

Approximately 13.0 ha (32.1 acres) of land would be cleared for all the approved or proposed projects addressed in this cumulative impact assessment. Operation of these facilities would result in the transport and storage of low-level and TRU wastes and spent nuclear fuel at ORNL. Releases of hazardous material or radioactive isotopes from storage facilities would not be expected under normal operation. The cumulative impacts of these reasonably foreseeable actions are discussed in the following paragraphs.

\subsubsection{Groundwater Hydrology and Quality Impacts}

Construction and operation of the actions in Melton Valley are not expected to result in cumulative impacts to groundwater hydrology and quality. Implementation of groundwater suppression techniques at individual sites could have minimal localized effects on the groundwater table. Lowering of the groundwater table by approximately $0.3 \mathrm{~m}(1 \mathrm{ft})$ could occur over small areas. Materials used to backfill pipeline trenches could be more permeable than native soils, creating preferred pathways for groundwater movement. Containment features incorporated into the design of the facilities would minimize the potential for movement of contaminants from these facilities into groundwater. During construction, accidental releases of construction liquids could occur. However, rapid spill emergency response would minimize impacts to groundwater.

\subsubsection{Surface Water Hydrology and Quality Impacts}

Construction of the proposed spent nuclear fuel storage area, in addition to the other Melton Valley actions included in this cumulative assessment, would result in clearing and grading of additional lands [approximately 13.0 ha (32.1 acres)] and potential sediment mobilization and transport into nearby surface waters. The potential for eroded material to reach the stream and have an adverse impact on water quality increases as more area in the watershed is disturbed. Impacts to surface water are expected to be minimal because (1) most of the proposed facilities are not adjacent to surface waters, (2) many of the streams in the construction areas are intermittent during part of the year, (3) only a portion of the total area would be under construction at any one time, and (4) best management practices (e.g., hay bales, silt fences) would be implemented to reduce impacts.

Construction and operation of numerous production and storage facilities in Melton Valley increase the potential for accidental releases of contaminants to the environment and 
potential transport of these contaminants into the aquatic environment. However, cleanup of any spills of hazardous materials following the ORNL Spill Prevention, Control, Countermeasures, and Contingency :Plan (September 1985) would minimize the potential for impacts to surface waters.

Clearing vegetation and replacing it with buildings and/or concrete pads could cause faster and greater runoff of storm water because there would be less natural vegetation and ground surface to allow absorption and longer retention. Natural buffers of more than $30 \mathrm{~m}$ $(98 \mathrm{ft}$ ) between the areas developed and streams such as Melton Branch should be adequate to allow runoff to be slowed and absorhed before reaching the creeks. Retention ponds could be used to collect runoff and reduce impacts on surface water quality and hydrology if projects are located closer to streams than $30 \mathrm{~m}$ (98 ft) or if an impact is anticipated.

Several of the projects consilered in this cumulative impacts assessment would be constructed using large amounts of concrete. To prevent the $\mathrm{pH}$ of water running off of those facilities from exceeding the NPDES upper limit of 9.0, carbon dioxide could be automatically bubbled through the water when the $\mathrm{pH}$ is above 9.0 to bring it into compliance before it is discharged as is done at the IWMF (isee Sect. 4.2.1).

Finally, the ORNL Biological Monitoring and Abatement Program, whose surveys have shown improvement in water quality in Melton Valley in the last few years, will continue to monitor water quality and aquatic biota there. Thus, any deterioration of water quality should be quickly detected allowing ineasures to be implemented to correct the problem as necessary.

\subsubsection{Wetlands}

Construction has the potential to result in sediment transport and deposition in wetlands. Sediment deposition occurs in wetland areas under natural conditions; however, excessive sediment deposition can have an adverse impact on wetland ecology. In general, without the use of sediment control naeasures, the effects of construction at several sites or larger areas would be additive. Although there is potential for sediment transport to wetlands from some of the projects proposed for Melton Valley, especially to small headwater wetlands close to construction areas, use of best management practices during construction and operation would minimize sediment transport.

Clearing vegetation and replacing it with buildings and/or concrete pads could cause faster and greater runoff of storm water because there would be less natural vegetation and ground surface to allow absorption and longer retention. Such changes in hydrology might impact headwater wetlands and their plants. Use of settling ponds could retard runoff and minimize such impacts.

Wetland surveys have been conducted for each proposed or planned site. All wetlands that occur near any of the proposed sites would be flagged before construction to ensure their 
protection from impacts due to construction of individual projects. For the wetlands most likely to be affected, a $15 \mathrm{~m}$ ( $50 \mathrm{ft}$ ) buffer around them would be adequate to reduce potential impacts. These protective measures would also prevent significant cumulative effects. Thus, with careful planning and follow through, the proposed facilities in Melton Valley would not be expected to have separate or cumulative adverse effects on wetlands.

\subsubsection{Aquatic Ecology}

The effects of sedimentation in small streams are generally additive and result in habitat degradation or loss and ultimately in changes in community composition of the aquatic environment (see Sect. 4.1.1). Disturbance of only a small portion of the overall area at any one time by construction activities, in addition to the use of best management practices during construction and operation at all sites, would minimize impacts to surface water quality and, consequently, to aquatic biota. As more land in the watershed is disturbed, the potential for eroded material to reach the stream, to accumulate, and to have an adverse impact on aquatic biota increases.

Biological Monitoring and Abatement Program surveys have shown an increase in fish and macroinvertebrate populations in Melton Branch in the last few years in response to remedial actions at ORNL. Adequate planning and control measures should ensure that this trend continues and is not reversed by increased sedimentation and habitat alteration. Since the Biological Monitoring and Abatement Program will continue to monitor water quality in Melton Branch, any deterioration of water quality should be detected allowing measures to be implemented to correct the problem as necessary.

\subsubsection{Terrestrial Ecology}

Cumulative impacts on local and regional terrestrial ecosystems include the loss of natural vegetation and reductions in wildlife populations due to habitat loss and forest fragmentation. Construction and operation of each facility in Melton Valley would result in a loss of some native forest habitat and associated wildlife. These effects are generally additive.

Forest fragmentation affects some wildlife species (e.g., ovenbird, yellow-billed cuckoo, wood warblers, red-shouldered hawk) which require large areas of undisturbed forest. To protect forest species that generally do not reproduce in nonwooded habitats, forested areas at least 100 ha (247 acres) or larger are needed (Askins 1995, Robinson et al. 1995). Even species preferring edges of forests (e.g., indigo bunting), nest more successfully in less fragmented landscapes.

Some species that require large forested areas, especially neotropical migratory songbirds, could be adversely affected by increase predation and parasitism from species that live in openings and edges and hunt in surrounding forest. Parasites such as cowbirds, for 
example, are active within 100-200 m (328-656 ft) of forest edge and can severely affect reproductive success of songbirds in fragmented forests (Askins 1995, Robinson et al. 1995). Extensive forests not only protect forest species but provide a source of recolonization of more fragmented forests that are too small to be self-sustaining. Songbird declines also could lead to other damaging effects including lea $[-$ damage of forest trees due to population outbreaks of leaf-feeding insects (Askins 1995, Robinson et al. 1995).

In general, as forest cover is removed from more areas within Melton Valley, smaller populations of species that require large forested areas could occupy the remaining forest. Other species which use openings and edges of forests and already occupy abundant habitat associated with existing disturbed sites would become even more abundant.

Many species requiring extensive forest might be impacted by forest fragmentation in Melton Valley. One such species which is known to occur there and for which data are available is the red-shouldered hawk. The optimal habitat for a pair of red-shouldered hawks is approximately 500 ha $(1,200$ acres) of primarily forest land, with less than $15 \%$ of the total area in clearings smaller than about 4 ha (10 acres). These birds reuse the same area for many years, often reusing the same tree ard the same nest, if available. The hawk often nests near roads and probably would not be affected by nearby traffic. There has been an active nest located in an oak tree in one of the thottomlands in the eastern part of Melton Valley. A buffer zone of unfragmented forest of about $200-\mathrm{m}(650 \mathrm{ft})$ radius around the nest that includes surrounding riparian habitat would probably ensure successful nesting and rearing of young.

Site clearing would create scme opportunity for erosion. These areas would need to be planted with native species of vegetation to stabilize soil and minimize erosion, as outlined in Executive Order 11987, "Exotic Organisms," and DOE 5400.1/AI-1, which restrict the introduction of exotic species into netural ecosystems on federally owned land.

The proposed actions in Melton Valley are not expected to have separate or cumulative adverse effects on rare plants. The state-listed endangered lilies growing on SWSA 7 at the eastern end of Melton Valley could be indirectly affected if there were changes in hydrology. However, the wetland and floodplain areas where they are growing would be protected from disturbance, runoff, and siltation. Appendix A summarizes compliance with the Endangered Species Act of 1973.

The overall impact on the wildlife habitats of ORR and the surrounding region of the projects proposed for Melton Valley would be relatively small since the entire acreage of the proposed sites is approximately 13 ha (32 acres). About $85 \%$ of the land is forested on the approximately 809 ha (2000 acres) of Melton Valley between Highway 95 and the eastern boundary of SWSA 7. Construction for these proposed actions would, therefore, result in less than an additional $1 \%$ of cleared forest in this part of Melton Valley.

However, forests of the ORJR are representative of ecosystems that are increasingly threatened by human development (Noss et al. 1995). ORR is a uniquely large and continuously forested area comparecl with the surrounding landscape (Mann et al. in press). 
The Nature Conservancy has identified the eastern end of Melton Valley as one of three landscape complexes on the ORR of ecological importance because of concentrations of rare species, rare ecological communities, and large blocks of high-quality native vegetation (Nature Conservancy 1995). Minimizing clearing of forest during construction would help reduce fragmentation.

Construction of the proposed facilities in Melton Valley considered in this evaluation would make a minor additional contribution to the cumulative impacts on ORR vegetation and wildlife due to all recent, current, and proposed actions on ORR. However, these projects in Melton Valley add to progressive fragmentation of forest on ORR which could have a disproportionately negative effect on interior forest populations and migratory bird species in the region.

DOE's recent (e.g., last ten years), currently proposed, and possible future actions, including property sales and numerous construction projects in various areas on $O R R$, have usually had or would have minor individual impacts because most of the actions affect only a relatively small area. However, some projects, not specifically included in this analysis, would impact large areas [e.g., Parcel A which was recently sold to the city of Oak Ridge, the proposed lease of 405 ha (1,000 acres) east of K-25 to the East Tennessee Economic Council, the proposed Spallation Neutron Source which might take an area of up to 256 ha (632 acres)]. In total, therefore, the actions in Melton Valley, in addition to all the other on-going and potential actions on the ORR, could have considerable cumulative impact on ORR vegetation and wildlife.

\subsubsection{Air Quality}

Temporary and localized increases in atmospheric concentrations of carbon monoxide, nitrogen dioxide, volatile organic compounds, and particulate matter would result from exhaust emissions of heavy construction vehicles, diesel generators, and other construction equipment. Because of the small scale of the proposed activities, these emissions would not add appreciably to existing levels of pollutants and would have negligible impacts on ambient air quality.

Fugitive dust would result from excavation and earthwork during construction activities. The impact of constructing any one building would be negligible. However, more than one site may be disturbed at any one time. Therefore, the cumulative impacts of simultaneous construction of several sites were modeled using the EPA-recommended Industrial Source Complex (ISC2) Short-Term air dispersion model (EPA 1992). All sites were assumed to be under construction at the same time [a total of approximately 14 ha (34 acres) of disturbed areal. It was further assumed in the modeling that no dust suppression measures (e.g., sprinkling) would be used at any time. An average emission factor for total suspended particulate matter of $1.02 \mathrm{~g} / \mathrm{ha} / \mathrm{s}$ (1.2 tons/acre/month) (EPA 1985) was used, and $30 \%$ of that amount was assumed to be respirable particulate matter (EPA 1988a). Respirable particulate 
matter is defined as particles of $10 \mu \mathrm{m}$ or less in diameter and is therefore abbreviated PM-10. National Ambient Air Quality Standırds (NAAQS) exist for annual and 24-h averages of PM-10 concentration.

The wind was assumed to be blowing toward the nearest residential area [Shoreline Estates, about $3 \mathrm{~km}$ ( 2 miles) southeist of the SWSA 7 area] at a speed of $1 \mathrm{~m} / \mathrm{s}$ (2.2 mph). Flat terrain was assumed for this fugitive dust analysis. These assumptions are all conservative. That is, they lead to overestimates of the ambient air concentrations of PM-10.

Two approaches were taken to estimate the maximum 24-h average concentrations of PM-10 resulting from the proposed activities. In the first approach, stable meteorological conditions were assumed. These conditions only occur at night, so the simulated concentrations were multiplied by 0.4 as per EPA (1988b) to arrive at an estimate of the maximum 24-h average to compare with the corresponding NAAQS. In the second approach, neutral stability (which can persist for $24 \mathrm{~h}$ ) was assumed and the resulting simulated concentrations were taken as the estimate of the maximum 24-h average. The highest of these figures (obtained by the first approach) was multiplied by 0.25 as per EPA (1988b) to arrive at a conservative estimate of annual average concentration of PM-10 that would result from all proposed activities occurring simultaneously. These figures were added to the background concentration from monitoring data for Loudon County, Tennessee. Emissions from the stack at the ORNL steam plant, a local source that is not accounted for in the Loudon County survey, were also included in the modeling.

The annual average concentration of PM-10 was simulated to increase by $20 \mu \mathrm{g} / \mathrm{m}^{3}$. When added to the background value of $31 \mu \mathrm{g} / \mathrm{m}^{3}$, the result exceeds the NAAQS for annual average PM-10 concentration $\left(50 \mu \mathrm{g} / \mathrm{m}^{3}\right)$ by $1 \mu \mathrm{g} / \mathrm{m}^{3}$. The maximum increase in PM-10 for a 24-h period was simulated as $80 \mu \mathrm{g} / \mathrm{m}^{3}$. When added to the background value of $61 \mu \mathrm{g} / \mathrm{m}^{3}$, the result is still less than the corresponding NAAQS for PM-10 averaged over a 24-h period $\left(150 \mu \mathrm{g} / \mathrm{m}^{3}\right)$.

Because of the conservative :ature of the modeling, the simulated PM-10 concentrations probably represent an unrealistic situation. Exceedance of the NAAQS would not be expected as a result of the proposed activities, even if they were all occurring simultaneously. However, it is generally recommended that the disturbed areas be sprinkled with water, or other dust suppression measures be implemented, on particularly dusty days to mitigate possible nuisance or health hazards to workers resulting from inhalation of particulate matter.

Airborne ${ }^{90} \mathrm{SrTiO}_{3}$ was also rnodeled. Assuming (1) the concentration of ${ }^{90} \mathrm{SrTiO}_{3}$ in the soil at the site of the construction activities is $0.037 \mathrm{~Bq} / \mathrm{g}(1 \mathrm{pCi} / \mathrm{g}$ ) (a conservative estimate of the radioactivity at SWSA 5), and (2) the construction activities would increase the annual average atmospheric concentration of soil particles by $20 \mu \mathrm{g} / \mathrm{m}^{3}$ (the conservative estimate given above), then the radioactivity of the air would nominally increase by $7.4 \times 10^{-7} \mathrm{~Bq} / \mathrm{m}^{3}$ $\left(2 \times 10^{-5} \mathrm{pCi} / \mathrm{m}^{3}\right)$. For comparison, the activity of radon in outdoor air is about $100 \mathrm{pCi} / \mathrm{m}^{3}$ 
(NCRP 1984), or more than $10^{6}$ times the estimated increase from ${ }^{90} \mathrm{SrTiO}_{3}$ if the proposed activities were all taking place simultaneously. That is, the ${ }^{90} \mathrm{SrTiO}_{3}$ would be expected to increase the natural background radioactivity of the air by less than $0.0001 \%$. It should be noted that this is a very conservative estimate, based on the assumptions that all waste management sites would be disturbed simultaneously, that the radioactivity of the suspended soil is the same as that at SWSA 5 (where it is about an order of magnitude higher than typical concentrations in the area), and that no measures would be used to suppress fugitive dust.

\subsubsection{Historic and Archaeological Resources}

Archaeological and historical surveys have been or will be completed in Melton Valley. The only currently known historical sites in Melton Valley include the Jones and Jenkins house sites (DuVall and Associates 1992). None of the proposed sites is on either of these historical sites, and therefore, no impacts are expected on archaeological or historical resources in Melton Valley. For all proposed projects, National Historic Preservation Act Sect. 106 consultation with the State Historic Preservation Officer would be carried out. For the proposed actions that have undergone state consultation, no objections or recommendations were given regarding construction of the proposed projects. Proposed projects awaiting correspondence with the State Historic Preservation Officer would follow their recommendations to ensure that proper measures are undertaken to protect archeological resources during construction and operation of the proposed facilities.

\subsubsection{Health and Safety}

The construction and operation of the proposed or planned actions in Melton Valley could result in additional injuries, illnesses, or radiation exposures. Injuries from construction and operation equipment are considered to be standard industrial accidents. Workers would comply with OSHA regulations (29 CFR 1926) and ORNL safety provisions to mitigate the incidence of equipment-related injuries or illnesses.

Construction of each of these projects would involve excavation of soils contaminated with ${ }^{90} \mathrm{SrTiO}_{3}$. Radioactivity from ${ }^{90} \mathrm{SrTiO}_{3}$ is from beta particles. Radiation exposure could, therefore, result in external exposures to the skin and internal exposures from inhalation of contaminated, airborne soil particles. Strontium-90 is known to absorb readily into the bloodstream and deposit in the bone. However, ${ }^{90} \mathrm{SrTiO}_{3}$ is an insoluble compound and would tend to remain in the respiratory tract if inhaled.

To bound exposures, the same conservative assumptions used in the air quality section (Sect. 4.4.6) are used here. Assuming all the soil is contaminated, external exposures to the skin from the ${ }^{90} \mathrm{SrTiO}_{3}$ would result in an annual EDE of approximately $8.7 \times 10^{-6} \mathrm{mSv}$ $\left(8.7 \times 10^{-4} \mathrm{mrem}\right)$. This is $0.0002 \%$ of the average individual background level. Exposure 
from inhalation of airborne particulates is based on the conservative air concentration of $7.4 \times 10^{-7} \mathrm{~Bq}\left(2 \times 10^{-5} \mathrm{pCi} / \mathrm{m}^{3}\right)$, presented in the air quality assessment (Sect. 4.4.6). The associated annual EDE from inhalation would be approximately $2 \times 10^{-5} \mathrm{mSv}$

$\left(2 \times 10^{-3} \mathrm{mrem}\right)$. This is about $0.01006 \%$ of the average annual individual background level of $3.6 \mathrm{mSv}$ (360 mrem). Therefore, using conservative assumptions, such as (1) all soils are contaminated above the average levils found in SWSA 7, and (2) all excavation is conducted simultaneously for all activities in Nelton Valley, the impacts on an individual's radiation exposure are negligible. This asses:ment bounds impacts for any individual excavation activity included in this cumulative impact assessment.

Cumulatively, operational a:tivities in Melton Valley (Fig. 4.1) would represent an increase in the radioactive waste management activities at ORNL. ${ }^{1}$ However, waste operators at ORNL would continue to rotate between jobs, comply with DOE Order 5480.11, and meet ALARA goals. Precise changes in exposures due to operations of all the actions are difficult to estimate. The annual dose to waste operations radiation workers would be expected to vary little from the 1991 average measurable exposure of $0.40 \mathrm{mSv} /$ year (40 mrem/year) (see Sect. 3.2.2). This is well below the DOE limit of $50 \mathrm{mSv} /$ year ( $5 \mathrm{rem} /$ year), the ORNL ALARA goal of $6.5 \mathrm{mSv} /$ year (0.65 rem/year), and the Energy Systems administrative control level of $15 \mathrm{mSv} /$ year (1.5 rem/year). Therefore, there would be no significantly increased radiological risk to workers, and the: addition to cumulative impacts on worker health and safety during incident-free operatior of this action would be negligible.

Some of the proposed facilities would handle mixed waste, thereby potentially exposing workers to hazardous materials. These facilities would handle only small amounts of hazardous material (e.g., $25 \mathrm{mg} / \mathrm{L}$ of cadmium) that would be mixed with a larger inventory of radioactive waste [e.g., in a 208-L (55-gal) drum]. The hazardous waste component of individual operations at the proposel facilities would not pose a threat because the quantities would be sufficiently small. Measures taken to control radiological hazards would also generally protect workers from the hazardous constituents in the mixed waste, except for highly volatile chemicals.

Public risk from radiological or hazardous materials would also be negligible because all the waste would be well contained and the overall radiological doses to off-site individuals would increase only slightly (probably unmeasurably). DOE Order 5400.5, "Radiation Protection of the Public and the Environment," limits the EDE that an off-site individual may receive from all exposure pathways and all radionuclides released from ORR during 1 year to no more than $1.0 \mathrm{mSv}(100 \mathrm{mrem})$. In 1993, the maximum predicted EDE from exposure through all pathways was $0.03 \mathrm{mSv}$ (3 mrem), 3\% of the DOE Order 5400.5 limit (Kornegay et al. 1994). Any small increase due to cumulative impacts from the waste storage activities assessed in this section would not bt: expected to change current experience measurably, which

\footnotetext{
${ }^{1}$ Radioactive waste management is assumed to include the management of SNF.
} 
is well below the DOE limit. The cumulative impact on health and safety of the waste operation facilities would be negligible.

The proposed facilities would represent an increase in radioactive waste inventory in the immediate area and would thereby increase the health hazard to the workers and members of the public who may travel near to the area. However, the hazard is passive and only becomes a problem (i.e., a risk) when the radioactive material becomes mobilized during an incident. Operation of numerous storage facilities in an area increases the potential for accidental releases of contaminants to that immediate area but does not change materially the overall potential for accidents per storage facility. That is, individual incidents do not change in probability; however; with more facilities, there is a greater likelihood for an effect at the region of greater facility density. Even with all the proposed facilities, impacts on the public health are expected to be small.

\subsubsection{Transportation}

Transportation operations associated with the proposed Melton Valley facilities are not expected to have major cumulative impacts during normal operations. For the assessments completed, the potential transportation impacts from both incident-free and accident conditions have been negligible for each individual facility.

Operating these planned or proposed facilities in Melton Valley would not greatly alter the transportation risks posed by a particular facility but would increase the overall health hazard potential to the workers and the public in the immediate area as a result of the increased cumulative quantities of radioactive waste being shipped. Even after a postulated accident, the effects would be localized and the actions of emergency response teams should prevent any large population exposures. Increased traffic flow would increase the risk of a vehicular accident, but this fact was considered in this and previous assessments by using conservative traffic volumes and accident rates.

Therefore, cumulative impacts from shipment of radiological or hazardous materials are expected to be negligible even during concurrent operation of multiple facilities. However, it is not possible to quantitatively assess cumulative transportation impacts for on-going transportation activities and proposed transportation activities since the information needed to complete this assessment is not available for on-going operations. The individual doses associated with each facility would be quite low and well below other operational doses such as those from package handling that occurs during waste transfer to storage casks. 


\section{REFERENCES}

Askins, R. A. 1995. "Hostile Land:capes and the Decline of Migratory Songbirds." Science, Vol. 267, pp. 1956-7.

Awl, D. J. 1995. JAYCOR, Oak Ridge, Tenn., personal communication to M. S. Salk, Environmental Sciences Division, Oak Ridge National Laboratory, Oak Ridge, Tenn., July 20.

BNI (Bechtel National, Inc.) 1994. Draft Remedial Investigation Report on Waste Area Grouping 5 at Oak Ridge Nutional Laboratory, Oak Ridge, Tennessee, Appendix B: Technical Findings and Conclusions, DOE/OR/01-1326\&D0/V3, Oak Ridge, Tennessee, December.

Chance, W. W. June 1991. Oak Ridge Reservation Site Development and Facilities Utilization Plan, 1990 Update, Oak Rillge National Laboratory, Oak Ridge, Tenn.

Cunningham, M. and L. Pounds. 1991. Resource Management Plan for the Oak Ridge Reservation, Vol. 28: Wetlands on the Oak Ridge Reservation, ORNL/NERP-5, Oak Ridge National Laboratory, Oak Ridge, Tenn.

Cunningham, M., Pounds, L., and l'arr, P. 1988. Vegetation of Four Sites on the Oak Ridge Reservation Proposed for Low-level Waste Disposal, report to P.D. Parr, Environmental Sciences Division, National Environmental Research Park, Oak Ridge National Laboratory, Oak Ridge, Tenn.

DOE (U.S. Department of Energy) 1983. Resource Management Plan for the Oak Ridge Reservation: Appendix B: Archaeological Considerations. In DuVall and Associates. An Archaeological Reconnaissance of the Solid Waste Storage Area (SWSA-7) at the Oak Ridge National Laboralory, Oak Ridge Reservation, Tennessee 1992, prepared for Martin Marietta Energy Systems, Inc., Oak Ridge, Tenn.

DOE (U.S. Department of Energy) 1992. Environmental Assessment - Receipt and Storage at Oak Ridge National Laboralory, Oak Ridge, Tennessee of Transuranic Waste and Mixed Oxide Waste from Nuclear Fuel Services, Inc., prepared by Oak Ridge National Laboratory, Oak Ridge, Teın., October.

DOE (U.S. Department of Energy) 1994. Construction of Mixed Waste Storage RCRA Facilities, Buildings 7668 and 7669, DOE/EA-0820, Washington, D.C., April.

DOE (U.S. Department of Energy) 1995a. Construction and Operation of Transuranic and Transuranic Mixed Waste Retrievable Storage Facilities at Oak Ridge National Laboratory, Oak Ridge, Telinessee, DOE/EA-0349, Oak Ridge Operations Office, Oak Ridge, Tenn., January. 
DOE (U.S. Department of Energy) 1995b. Melton Valley Storage Tank-Capacity Increase Project Environmental Assessment, DOE/EA-X10-354, Oak Ridge Operations Office, Oak Ridge, Tenn., April.

DOE (U.S. Department of Energy) 1995c. Department of Energy Programmatic Spent Nuclear Fuel Management and Idaho National Engineering Laboratory Environmental Restoration and Waste Management Program Final Environmental Impact Statement (PEIS), Volume 1, Appendix A-L, April 1995.

DuVall \& Associates 1992. An Archaeological Reconnaissance of the Solid Waste Storage Area (SWSA-7) at the Oak Ridge National Laboratory, Oak Ridge Reservation, Tennessee 1992, prepared for Martin Marietta Energy Systems, Inc., Oak Ridge, Tenn., May.

ERCE 1991. Geotechnical Study HFIR Maintenance Facility at ORNL (X-10) Oak Ridge, Tennessee MMES Subcontract 88B 99977V Requisition Number C05. Martin Marietta Energy Systems. Knoxville, Tenn., June 20.

EPA (U.S. Environmental Protection Agency) 1985. Compilation of Air Pollutant Emission Factors, Vol. I: Stationary Point and Area Sources, 4th ed. EPA Publication AP-42, Research Triangle Park, N.C.

EPA (U.S. Environmental Protection Agency) 1988a. Gap Filling for PM-10 Emission Factors for Selected Open Area Dust Sources, EPA-450/4-88-003, Research Triangle Park, N.C.

EPA (U.S. Environmental Protection Agency) 1988b. Screening Procedures for Estimating the Air Quality Impact of Stationary Sources, EPA-450/4-88-010. Office of Air Quality Planning and Standards, Research Triangle Park, N.C.

EPA (U.S. Environmental Protection Agency) 1992. User's Guide for the Industrial Source Complex (ISC2) Dispersion Models, EPA-450/4-92-008a (Vol. 1). Office of Air Quality Planning and Standards, Research Triangle Park, N.C.

IAEA (International Atomic Energy Agency) 1992. Effects of Ionizing Radiation on Plants and Animals at Levels Implied by Current Radiation Protection Standards, Technical Reports Series No. 332, Vienna, Austria.

Hatcher, R. M. 1994a. Tennessee Wildlife Resources Commission Proclamation: Endangered or Threatened Species, Proc. 94-17.

Hatcher, R. M. 1994b. Tennessee Wildlife Resources Commission Proclamation: Wildlife in Need of Management, Proc. 94-16.

Kennedy, R. P. et al. 1990. Design and Evaluation Guidelines for Department of Energy Facilities subjected to Natural Phenomena Hazards, UCRL-15910, Lawrence Livermore National Laboratory, Livermore, Calif. 
Kitchings, J. T. and L. K. Mann 19:6. A Description of the Terrestrial Ecology of the Oak Ridge Environmental Research Park, ORNL/TM-5073, ORNL, Oak Ridge, Tenn.

Klein, J. A. 1995. Martin Marietta Energy Systems Internal Correspondence, to D. W. Turner, March 14, 1995 re: Oak Ridge Spent Nuclear Fuel Inventories.

Kornegay, F. et al. 1994a. Environmental Monitoring and Surveillance on the Oak Ridge Reservation: 1993 Date. E's/ESH-48, Martin Marietta Energy Systems, Inc., Oak Ridge, Tenn., December.

Kornegay, F. et al. 1994b. Oak Ridge Reservation Environmental Surveillance Report for 1993, ES/ESH-47, Martin Mlarietta Energy Systems, Inc., Oak Ridge, Tenn., November.

Kroodsma, R. 1985. Ecological Characterization of Terrestrial Biota of the Proposed Solid Waste Storage Area (SWSA) 7, report to L. K. Mann, Environmental Sciences Division, Oak Ridge National Laboratory, Oak Ridge, Tenn.

Kroodsma, R. 1987. Resource Management Plan for the Oak Ridge Reservation, vol. 24: Threatened and Endangered Animal Species. ORNL/ESH-1/V24, Oak Ridge National Laboratory, Oak Ridge, Tenn.

Loar, J. M. et al. 1987. First Annual Report on the ORNL Biological Monitoring and Abatement Program, ORNL.TM-10399, Oak Ridge National Laboratory, Oak Ridge, Tenn.

Loar, J. M. et al. 1988. Second Annual Report on the ORNL Biological Monitoring and Abatement Program, ORNL/TM-10804, Oak Ridge National Laboratory, Oak Ridge, Tenn.

Loar, J. M. et al. 1989. Third Annual Report on the ORNL Biological Monitoring and Abatement Program, ORNL.TM-11358, Oak Ridge National Laboratory, Oak Ridge, Tenn.

Loar, J. M. et al. 1990. Fourth Anjual Report on the ORNL Biological Monitoring and Abatement Program, ORNL'TM-11544, Oak Ridge National Laboratory, Oak Ridge, Tenn.

Loar, J. M. et al. 1991. Fifth Annual Report on the ORNL Biological Monitoring and Abatement Program, Draft K'eport, ORNL/TM-12143, Oak Ridge National Laboratory, Oak Ridge, Tenn.

Loar, J. M. et. al. 1992. Sixth Annual Report on the ORNL Biological Monitoring and Abatement Program, Draft Kleport, ORNL/TM-12083, Martin Marietta Energy Systems, Inc., Oak Ridge National Laboratory, Oak Ridge, Tenn. 
Mann, L. K. et al. In press. Protection of Biota on Nonpark Public Lands: Examples from the U.S. Department of Energy Oak Ridge Reservation. Environmental Management.

McCold, L. N. et al. 1992. Phase 1 Environmental Report for the Advanced Neutron Source at Oak Ridge National Laboratory, ORNL/TM-12069, Oak Ridge National Laboratory, Oak Ridge, Tenn., February.

Mitchell, J. M. 1995. JAYCOR, Oak Ridge, Tenn., personal communication to M. S. Salk, Environmental Sciences Division, Oak Ridge National Laboratory, Oak Ridge, Tenn., July 20 and July 24.

Morrissey, C. M. 1995. Environmental Sciences Division, Oak Ridge National Laboratory, Oak Ridge, Tenn., personal communication to M. S. Salk, Environmental Sciences Division, ORNL, July 17.

Myrick et al. 1981. State Background Radiation Levels of Measurements Taken During 19751979. Union Carbine Corporation, Oak Ridge National Laboratory, Oak Ridge, Tenn.

NAS (National Academy of Sciences) 1990. Health Effects of Exposure to Low Levels of Ionizing Radiation, BEIR V Report, National Academy Press, Washington, D.C.

NCRP (National Council on Radiation Protection and Measurements) 1984. Evaluation of Occupational and Environmental Exposures to Radon and Radon Daughters in the United States, NCRP Report No. 78, Bethesda, Md.

NCRP (National Council on Radiation Protection and Measurements) 1987. Ionizing Radiation Exposure of the Population of the United States, NCRP Report No. 93, Bethesda, Md., September.

NSC (National Safety Council) 1992. Accident Facts 1992 Edition, Itasca, Ill.

Nature Conservancy 1995. Oak Ridge Reservation, Biodiversity, and the Common Ground Process: Preliminary Biodiversity Report on the Oak Ridge Reservation, communication to Patricia D. Parr, Environmental Sciences Division, from The Nature Conservancy, April 3.

Noss, R. F. et al. 1995. Endangered Ecosystems of the United States: A Preliminary Assessment of Loss and Degradation, Biological Report 28, USDI/NBS, Washington, D.C.

NRC (U.S. Nuclear Regulatory Commission) 1992. Occupational Radiation Exposure at Commercial Nuclear Power Reactors and Other Facilities 1989, Twenty Second Annual Report, NUREG-0713 Vol. 11, Office of Nuclear Regulatory Research, Washington, D.C.

ORNL 1988. Health, Safety, and Environmental Protection for Excavating Operations, Oak Ridge National Laboratory, ORNL/M-116/R1, Oak Ridge, Tenn., March. 
Robinson, S. K. et al. 1995. "Regicnal Forest Fragmentation and the Nesting Success of Migratory Birds." Science, Vol. 267, pp. 1987-90.

Rosensteel, B. A. 1995a. JAYCOR, Oak Ridge National Laboratory, Oak Ridge, Tenn., letter to J. Dickerman, Environmental Sciences Division, Oak Ridge National Laboratory, Oak Ridge, Tenn., May 9.

Rosensteel, B. A. 1995b. JAYCOR, Oak Ridge, Tenn., personal communication to M. S. Salk, Environmental Sciences Division, Oak Ridge National Laboratory, Oak Ridge, Tenn., July 17.

Rothschild, E. R. et al. 1984a. Geohydrologic Characterization of Proposed Solid Waste Storage Area (SWSA) 7, ORNL/TM-9314, Oak Ridge National Laboratory, Oak Ridge, Tenn., December.

Rothschild, E. R. et al. 1984b. Characterization of Soils at Proposed Solid Waste Storage Area (SWSA 7), ORNL/TM-9326., Oak Ridge National Laboratory, Oak Ridge, Tenn.

Ryon, M. G. 1988. "Fishes," pp. 203-232 in J. M. Loar (ed.), Second Annual Report on the ORNL Biological Monitorin!; and Abatement Program, ORNL/TM-10804, Oak Ridge National Laboratory, Oak Ridge, Tenn.

Setaro, J. A. 1992. Office of Radiation Protection, Oak Ridge National Laboratory, Oak Ridge, Tenn., personal communication to M. L. Socolof, Energy Division, ORNL, November 10.

Smith, J. G. 1988a. "Benthic Macroinvertebrates," pp. 164-202 in J. M. Loar ed., Second Annual Report on the ORNL Biological Monitoring and Abatement Program, ORNL/TM-10804, Ridge National Laboratory, Oak Ridge, Tenn.

Smith, J. G. 1988b. "Benthic macroinvertebrates," pp. 109-155. In G. R. Southworth ed., Ecological Evaluation of Bear Creek 19841087, Draft Report, Martin Marietta Energy Systems, Inc., Oak Ridge National Laboratory, Oak Ridge, Tenn.

Smith, J. G. 1992. "Benthic Macroinvertebrates," pp. 109-155 in G. R. Southworth ed., Ecological Effects of Contaminants and Remedial Actions in Bear Creek, ORNL/TM-11977, Oak Ridge National Laboratory, Oak Ridge, Tenn.

Smith, J. G. and M. G. Ryon 1989. Environmental Sciences Division, Oak Ridge National Laboratory Oak Ridge, Tena., letter to J. M. Loar, Environmental Sciences Division, Oak Ridge National Labora1ory, July 21.

Valentine, C. K. 1995. Office of Eavironmental Compliance, Oak Ridge National Laboratory, Oak Ridge, Tenn. personal sommunication to M. S. Salk, Environmental Sciences Division, ORNL, July 17. 
van der Leeden, F. et al. 1991. The Water Encyclopedia, Geraghty \& Miller Ground-Water Series, Lewis Publications, Chelsea, Michigan

Walker, B. A., et al. 1988. Data Package for the Low-Level Waste Disposal Development and Demonstration Program Environmental Impact Statement, ORNL/TM-10939/V1, Oak Ridge National Laboratory, Oak Ridge, Tenn.

Webster, D. A. 1976. A Review of the Hydrologic and Geologic Conditions Related to the Radioactive Solid Waste Burial Grounds at Oak Ridge National Laboratory, Tennessee, Open File Report 76-727, U.S. Geological Survey, Reston, Va. 
APPENDIX A

COMPLIANCE WITH REGULATIONS FOR THREATENED AND ENDANGERED SPECIES 
A-1

\section{APPENDIX A}

\section{COMPLIANCE WITH REGULA'TIONS FOR THREATENED AND ENDANGERED SPECIES}

This appendix summarizes (1) endangered species regulations as they apply to the management of the Oak Ridge Resesvation (ORR) by the Department of Energy (DOE), (2) recommendations of the Fish and Wildlife Service (FWS) and the state of Tennessee for endangered species activities on the ORR, and (3) DOE actions in response to these recommendations and regulations. In summary, the regulations require DOE to ensure protection of animals and plants listed under the Endangered Species Act (ESA) and animals listed by the Tennessee Wildlife Resources Commission. DOE is not required by state regulations to protect state-listed plant species on its property.

\section{A.1 COMPLIANCE WITH FEDHRAL AND STATE REGULATIONS}

\section{Federal regulations:}

Federal regulations to implement Section 7, Interagency Cooperation, of the ESA of 1973 (16 U.S.C. 1531 et seq.) require that DOE consider the impacts of its actions on plant and animal species listed by FWS as thrt:atened or endangered, on species proposed to be listed as threatened or endangered, and on areas designated or proposed for designation as critical habitats. In addition, while none of the substantive or procedural provisions of the Act applies to a species that is designated as a cindidate for listing (commonly known as a candidate species), the FWS advises federal agencies that it is prudent to take them in to account during environmental planning, such as in the preparation of NEPA documents. If these species are eventually listed as endangered or threatened, it may be necessary for DOE to consult with FWS to determine the impact of its actions on them.

Section 7 consultation for a "major construction activity" is initiated by DOE's contacting the FWS and asking for information on listed or proposed threatened or endangered species or designated or proposed critical habitats in the area of DOE's proposed action. "Major construction activity" is defined in 50 CFR 402.02 as "a construction project (or other undertaking having similar physical impacts) which is a major federal action significantly affecting the quality of the human environment as referred to in the National Environmental Policy Act" (NEPA). Whether a proposed project meets that definition is determined by an environmental assessment (EA) (40 CFR 1508.9) prepared in accordance with NEPA. If a threatened or endangered species would be affected by a small DOE construction project, the project might have to be defined as "significantly" (40 CFR 1508.27) affecting the environment and as a major federal action requiring an environmental impact statement (EIS) in accordance with 40 CFR 1502.3. 


\section{A-2}

For other proposed actions DOE determines whether listed or proposed species are present. If DOE determines that there are no listed or proposed endangered or threatened species or any designated or proposed critical habitats present in the area of a proposed action, or that if present, they will not be affected, and if FWS agrees with that determination, then no further action is required to comply with Sect. 7.

If DOE determines that any listed species or designated critical habitats may be affected, then informal or formal consultation needs to be initiated. The purpose of informal consultation is to determine if formal consultation or a conference is required. (See 50 CFR 402.13 for details.) During informal consultation, DOE and FWS discuss the effects of the proposed project on listed species and/or critical habitats and possible alternatives that might preclude the need for formal consultation. Although informal consultation is optional, it is highly recommended by FWS as a way to resolve any potential endangered species problems.

If DOE determines that any proposed species or critical habitats may be affected, then a conference needs to be initiated. The purpose of a conference is to resolve potential conflicts by informal discussions. The conclusions of these discussions should be recorded in an appropriate document by DOE. If the proposal to list the species or designate the habitat is eventually finalized, DOE may be required to initiate formal consultation. The record of the conference results would then be used as the basis of information for the formal consultation.

If FWS advises DOE that listed or proposed threatened and/or endangered species or designated or proposed critical habitats may be present in the area of proposed actions which are "major construction activities" and DOE determines that they may be affected, then a biological assessment must be prepared. For DOE actions which are not "major construction activities" and for which an EIS is not being prepared, DOE must still comply with Section 7 of the ESA, but a biological assessment is not required. However, for such projects, a biological assessment may be voluntarily prepared to assist DOE in its consultation or conference with FWS. In practice, a biological assessment is normally prepared when a DOE proposed action may affect a threatened and/or endangered species or critical habitat.

If a biological assessment determines that a listed species or designated critical habitat may be affected, or if DOE determines that a proposed minor construction project may affect a listed species, DOE must request formal consultation with FWS. If a biological assessment determines that a species proposed for listing or a habitat proposed for designation as critical may be affected, DOE must confer with the FWS. If DOE determines that no impact would occur and FWS concurs, no further consultation is required.

If a proposed action requiring the preparation of a biological assessment is identical or very similar to a previous action for which a biological assessment has already been prepared, the biological assessment requirement may be fulfilled for the proposed action by incorporating by reference the earlier biological assessment, plus any pertinent supporting data from other documents. A written document should be prepared that certifies that the proposed action involves similar impacts to the same species in the same geographic area, that no new species 
have been listed or proposed or new critical habitat designated or proposed for the action area, and that the biological assessment has been supplemented with any relevant changes in information. This information should be included in the EA or EIS prepared on the proposed action.

During any consultation, FW'S may recommend discretionary studies or surveys that may provide a better information base for assessing impacts on listed species [50 CFR 402.12(d)(2)]. Such studies are optional and not required.

\section{Tennessee regulations:}

The Tennessee Code Annotated Title 70, Chapter 8, and regulations of the Tennessee Wildlife Resources Commission prolect animal species listed by the state as endangered, threatened, or in need of managemeit. No person or agency may knowingly destroy a listed species or its habitat without a permit from the state.

Plant species listed by the Ttnnessee Department of Conservation are provided limited protection by the Tennessee Rare Plant Protection and Conservation Act of 1985 (Tennessee Code Annotated Title 11-26, Sects. :01-214). The act protects listed plants from indiscriminate collecting by plant collectors but does not prohibit landowners such as DOE from destroying listed plants on their own property. Thus, apart from federal requirements, DOE is not required to perform surveys for state-listed plants or to ensure that its proposed actions do not impact listed plants. Nevertheless, DOE attempts to protect all state-listed plant species occurring on ORR.

The Tennessee Wildlife Resiources Agency and the Tennessee Department of Conservation have been requested tc provide written descriptions of any surveys and documentation that DOE must perform or prepare to comply with state law.

\section{A.2 DOE ACTIONS CONCERNING COMPLIANCE WITH STATE AND FEDERAL REGULATIONS}

Personnel. The DOE Resource Management Organization for ORR includes two persons designated to coordinate issues concerning threatened and endangered ( $\mathrm{T} \& \mathrm{E}$ ) species- one person for plant specits and one for animal species. They serve as coordinators for consultation with state and federil agencies and for surveys for listed plants and animals on ORR. Activities of the DOE National Environmental Research Park on ORR also support studies of listed species that are known to occur on ORR. During 1994 and 1995, field surveys for T \& E species are being conducted throughout ORR as part of the environmental restoration project. No staff positions are designated and funded specifically for surveys or studies of listed species, and so such surveys and studies are limited.

Planning and documentation. As part of the planning process for construction projects, DOE prepares literature reviews and conducts surveys to determine whether any listed plant or animal species would be affected. The two endangered species coordinators of the 
Resource Management Organization have reviewed literature and other information on the status of listed plants and animals on ORR (Kroodsma 1987; Parr 1984; Cunningham et al. 1993; Pounds et al. 1993; King et al. 1994). Field surveys are conducted as necessary, and documentation is provided in categorical exclusions, EAs, and EISs.

Surveys. There is no evidence that any FWS-listed plant species occurs on ORR (Table A.1). Nevertheless, an attempt is made to conduct plant surveys for all state-listed, FWS-listed, and FWS candidate plants at all sites with natural habitats that would be affected by construction or operation of a proposed project. Many state-listed and FWS candidate plant species occur on ORR and are sometimes found on proposed construction sites. The federal candidate tall larkspur grows on calcareous soils in several locations on the ORR, but is not found in Melton Valley. The closest population is more than $2.4 \mathrm{~km}$ (1.5 miles) away in another valley.

There is evidence that one FWS-listed animal species occurs on ORR (Table A.1). A dead gray bat was found in a facility light fixture about $4 \mathrm{~km}$ (2.5 miles) from Melton Valley. Additional surveys for this species are currently in progress. The Indiana bat is another FWS-listed animal species for which there was sufficient evidence to indicate potential presence on ORR. A partial field survey (i.e., limited mist netting) was conducted in May 1992 at several sites in the floodplain of East Fork Poplar Creek in habitat that was suitable for this species, but no Indiana bats were trapped (Webb 1995). The bald eagle is an uncommon visitor or migrant and is not currently known to nest on the ORR. Previous studies have identified this area as suitable bald eagle nesting habitat, but of low quality (Buehler 1994). 
Table A.1. Status of rare species reported from the Oak Ridge Reservationa

\begin{tabular}{|c|c|c|c|}
\hline \multirow[b]{2}{*}{ Species } & & \multicolumn{2}{|c|}{ Legal status ${ }^{b}$} \\
\hline & & Federal & State \\
\hline \multicolumn{4}{|c|}{ Plants } \\
\hline Aureolaria patula & spreading false foxglove & $\mathrm{C} 2$ & $\mathbf{E}$ \\
\hline Cimicifuga rubifolia & Appalachian bugbane & $\mathrm{C} 2$ & $\mathbf{T}$ \\
\hline Delphinium exaltatum & tall larkspur & $\mathrm{C} 2$ & $\mathbf{E}$ \\
\hline Juglans cinerea & butternut & $\mathrm{C} 2$ & \\
\hline Cypripedium acaule & pink lady-slipper & & $\mathbf{E}$ \\
\hline Liparis loeselii & fen orchid & & $\mathbf{E}$ \\
\hline Diervilla lonicera & northern bush-honeysuckle & & $\mathbf{T}$ \\
\hline Fothergilla major & mountain witch-alder & & $\mathbf{T}$ \\
\hline Hydrastis canadensis & goldenseal & & $\mathbf{T}$ \\
\hline Lilium canadense & Canada lily & & $\mathbf{T}$ \\
\hline Panax quinquifolius & ginseng & & $\mathbf{T}$ \\
\hline Platanthera flava var hebiola & tuberculed rein-orchid & & $\mathbf{T}$ \\
\hline Platanthera peramoena & purple fringeless orchid & & $\mathbf{T}$ \\
\hline Elodea nuttallii & Nuttall's waterweed & & $\mathbf{S}$ \\
\hline Saxifraga careyana & Carey's saxifrage & & $\mathbf{S}$ \\
\hline Spiranthes ovalis & lesser lady's tresses & & $\mathbf{S}$ \\
\hline Carex gravida & heavy sedge & & $\mathbf{S}$ \\
\hline Draba ramosissima & branching whitlow grass & & $\mathbf{S}$ \\
\hline Juncus brachycephalus & small-headed sedge & & $\mathbf{S}$ \\
\hline Scirpus fluviatalis & river bulrush & & $\mathbf{S}$ \\
\hline \multicolumn{4}{|c|}{ Fish } \\
\hline Polyodon spathula & paddlefish & $\mathrm{C} 2$ & \\
\hline Phoxinus tennesseensis & Tennessee dace & & NM \\
\hline \multicolumn{4}{|c|}{ Amphibians and reptiles } \\
\hline $\begin{array}{l}\text { Aneides aeneus } \\
\text { Cryptobranchus alleganiensis }\end{array}$ & $\begin{array}{l}\text { green salamander } \\
\text { hellbender }\end{array}$ & $\begin{array}{l}\mathrm{C} 2 \\
\mathrm{C} 2\end{array}$ & NM \\
\hline
\end{tabular}


(Table A.1. Continued)

\begin{tabular}{|c|c|c|c|}
\hline \multirow[b]{2}{*}{ Species } & & \multicolumn{2}{|c|}{ Legal status $^{b}$} \\
\hline & & Federal & State \\
\hline \multicolumn{4}{|c|}{ Birds } \\
\hline Haliaeetus leucocephalus ${ }^{c}$ & bald eagle & $\mathbf{T}$ & $\mathbf{T}$ \\
\hline Falco peregrinus & peregrine falcon & $\mathrm{T}$ & $\mathrm{E}$ \\
\hline Aimophila aestivalis & Bachman's sparrow & $\mathrm{C} 2$ & $\mathrm{E}$ \\
\hline Ammodramus henslowii ${ }^{c}$ & Henslow's sparrow & $\mathrm{C} 2$ & \\
\hline Chlindonias niger & black tern & $\mathrm{C} 2$ & \\
\hline Dendroica cerulea & cerulean warbler & $\mathrm{C} 2$ & \\
\hline Thyromanes bewickii & Bewick's wren & $\mathrm{C} 2$ & $\mathbf{T}$ \\
\hline Pandion haliaetus & osprey & & $\mathbf{T}$ \\
\hline Ammodramus savannarum & grasshopper sparrow & & $\mathbf{N M}$ \\
\hline Accipiter striatus ${ }^{d}$ & sharp-shinned hawk & & $\mathbf{N M}$ \\
\hline Accipiter cooperit ${ }^{d}$ & Cooper's hawk & & NM \\
\hline Circus cyaneuse & northern harrier & & NM \\
\hline Anhinga anhingac & anhinga & & $\mathbf{N M}$ \\
\hline Casmerodius albac & great egret & & NM \\
\hline Contopus borealiss & olive-sided flycatcher & & NM \\
\hline Grus canadensis ${ }^{c}$ & sandhill crane & & NM \\
\hline Phalacrocorax auritusc & double-crested cormorant & & $\mathbf{N M}$ \\
\hline Sphyrapicus variusc & yellow-bellied sapsucker & & NM \\
\hline Tyto alba & common barn owl & & $\mathbf{N M}$ \\
\hline Egretta caerulead & little blue heron & & NM \\
\hline \multicolumn{4}{|c|}{ Mammals } \\
\hline Myotis grisescens & gray bat & $\mathbf{E}$ & $\mathbf{E}$ \\
\hline Sorex longirostris & southeastern shrew & & NM \\
\hline
\end{tabular}

aFrom Parr and Evans (1992), Cunningham et al. (1993), Kroodsma (1987), Pounds et al. (1993), King et al. (1994), and ongoing environmental restoration field surveys.

${ }^{b} \mathrm{E}=$ endangered, $\mathrm{T}=$ threatened, $\mathrm{Cl}, \mathrm{C2}=$ candidate, $\mathrm{NM}=$ in need of management, $\mathrm{S}=$ special concern in Tennessee.

'Uncommon visitor or migrant. Not currently known to nest on the Oak Ridge Reservation.

¿Summer. 


\section{A.3 REFERENCES}

Buehler, D. A. 1994. Bald Eagle Habitat Suitability on Melton Hill Reservoir and the Clinch River, ORNL/NERP-9, Oak Ridge National Laboratory, Oak Ridge, Tenn.

Cunningham, M. et al. 1993. Resource Management Plan for the Oak Ridge Reservation Vol. 29: Rare Plants on the Oak Ridge Reservation, ORNL/NERP-7, Oak Ridge National Laboratory, Oak Ridge, Tenn.

King, A. L., D. J. Awl, and C. A. Gabrielsen. 1994. Environmentally Sensitive Areas Surveys Program Threatened and Endangered Species Survey Progress Report, ORNL/ES/ER/TM-130, Oak Ridge National Laboratory, Oak Ridge, Tenn.

Kroodsma, R. L. 1987. Resource Management Plan for the Oak Ridge Reservation, Vol. 24: Threatened and Endangered Animal Species. ORNL/ESH-1/V24, Oak Ridge National Laboratory, Oak Ridge, Tenn.

Parr, P. D. 1984. Resource Management Plan for the Oak Ridge Reservation, Vol. 4: Endangered and Threatened Plant Species. ORNL-6026/V4, Oak Ridge National Laboratory, Oak Ridge, Tenn.

Parr, P. D. and J. W. Evans 1992. Resources Management Plan for the Oak Ridge Reservation, Vol. 27: Wildlije Management Plan. ORNL/NERP-6, Oak Ridge National Laboratory, Oak Ridge, Tenn.

Pounds, L. R., P. D. Parr, and M. (G. Ryon. 1993. Resource Management Plan for the Oak Ridge Reservation, Vol. 30: Oak Ridge National Environmental Research Park Natural Areas and Reference Areas--Oak Ridge Reservation Environmentally Sensitive Sites Containing Special Plants, Animals, and Communities. ORNL/NERP-8, Oak Ridge National Laboratory, Oak Ridge, Tenn.

Webb, J. W. 1995. Environmental Sciences Division (ESD), Oak Ridge National Laboratory (ORNL), Oak Ridge, Tenn. personal communication to M. S. Salk, ESD, ORNL, July 31. 
APPENDIX B

CONSULTATION LETTERS 
Tolophone: 615/574-4677

Tolofex: 615/576-8543

Mr. Terry Gupton

U.S. Soil Conservation Service

P.O. Box 203

Kingston, TN 37763

Dear Mr. Gupton:

We are preparing environmental assessments for several waste storage or treatment facilities on the Oak Ridge Reservation. Thes; projects involve building gravel storage pads, below ground storage or pumping structures, pipelines, and upgrading gravel access roads. A map showing the areas of concern is enclosed.

Please let me know if there are prime agricultural lands on any of these sites which might affect our assessment.

Thank you for your help. If you have any questions, please call me at (615) 574-4677.

Sincerely,

$$
\text { Soudir K. Mlewn }
$$

Linda K. Mann

Research Associate

\section{LKM:dld}

\section{Enclosures}




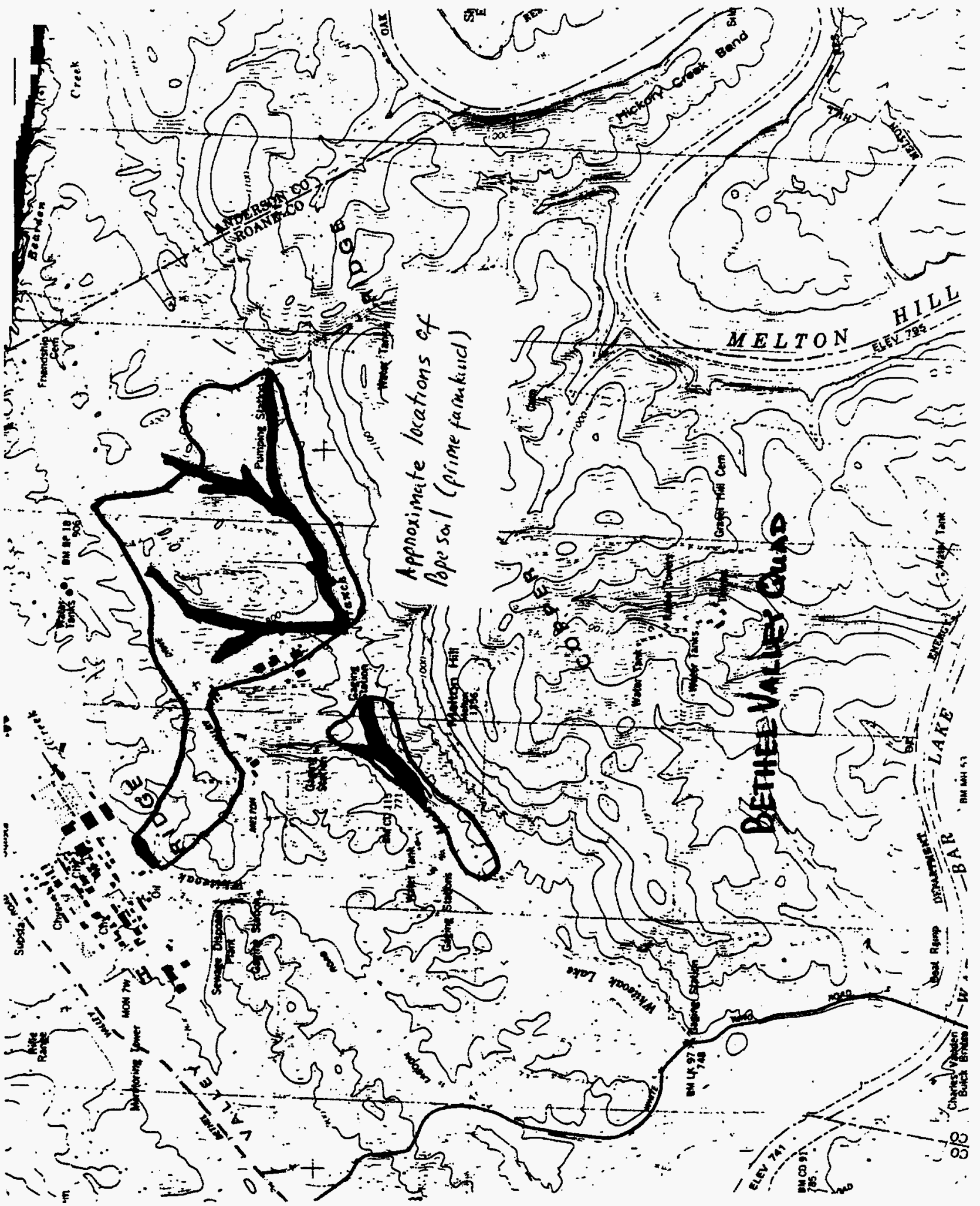


United States

Department of

Agriculture
Soil

Conservition

Service

\author{
F. 0. E0: 206 \\ Kinastan, TN 37703 \\ उ/29/93
}

Ms. Linda K. Wann

Environmental Sciences Division

Tak Fidge National Laboratorv

Fost Dffice Eci: 2018

Dak Ridqe, TN 378.31-0308

Dear Ms. Mann:

I have reviewed the seils map for the area that vau are making an enviranmental assessment. The map shows only ane s0i1 tipe that is prime farmland. The soil type is Fope. arr the mapl. This soil is lacated near small drainagewava and coccurs in narrow bavs on either side of the streanfber: These small narrow areas will probably be insignificant to the overall project.

Flease let me know if vou need inore information.

sincerely,

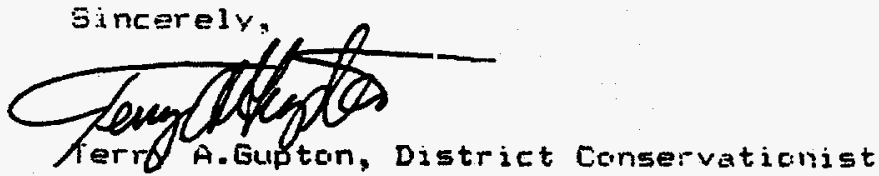

Enclosure

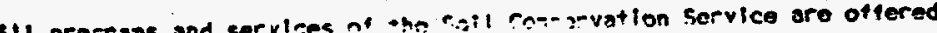

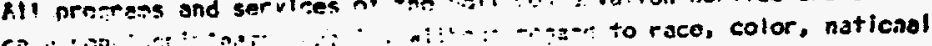

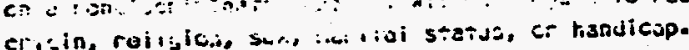




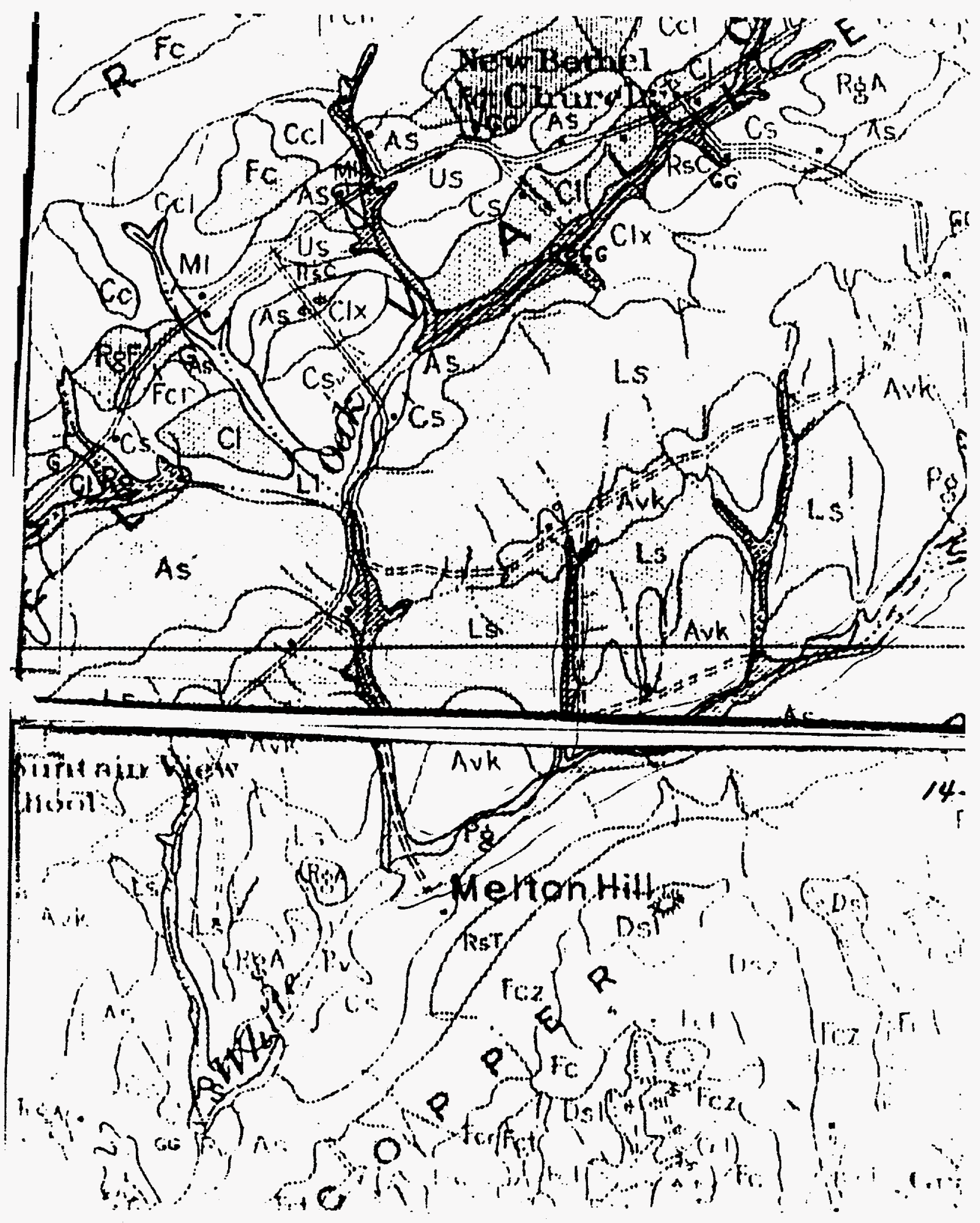




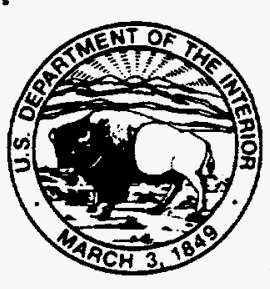

B-5

United States Department of the Interior

\author{
FISH AND WTLDLIFE SERVICE \\ 446 Neal Street \\ Cookeville, TN 38501
}

August 8, 1995

Ms. Linda Mann
Research Associate
Oak Ridge National Laboratory
P.O. Box 2008
Oak Ridge, Tennessee 37831-6038

Dear Ms. Mann:

Thank you for your letter and enclosures of July 10, 1995, regarding the Oak Ridge Reservation in Roane County. Tennessee. The Fish and Wildlife Service (Service) has reviewed the information submitted and offers the following comments.

Information available to the Service indicates that wetlands exist in the vicinity of the proposed project. However, our wetland determination has been made in the absence of a field inspection and does not constitute a wetland delineation for the purposes of Section 404 of the Clean Water Act or the wetland conservation provisions of the Food security Act. The Corps of Engineers or the Natural Resources Conservation Service should be contacted regarding the presence of regulatory wetlands and the requirements of wetland protection statutes.

According to our records, the following federally listed or proposed endangered or threatened species may occur in the project impact area:

\title{
Bald eagle (Haliaeetus leucocephalus) (E)
}

Gray bat (Myotis grisescens) (E)

In addition to listed species, there are species that, although not presently listed or proposed, are being considered for listing in the future. Status review (candidate) species that might occur in the vicinity of the proposed project are:

\section{Tall larkspur (Delghinium exaltitum) (SR)}

These species are not legally protected under the Endangered Species Act (Act) at this time, and consultation and biological assessment requirements of Section 7 of the Act do not currently apply to them. However, we would appreciate any measures you miçht implement to avoid impacting them. 


\section{B-6}

You should assess potential impacts and determine if the proposed project may affect the species. A finding of "may affect" could require initiation of formal consultation. We recommend that you submit a copy of your assessment and finding to this office for review and concurrence.

Thank you for the opportunity to comment on this action. If you have any questions, please contact Allen Robison of my staff at $615 / 528-6481$.

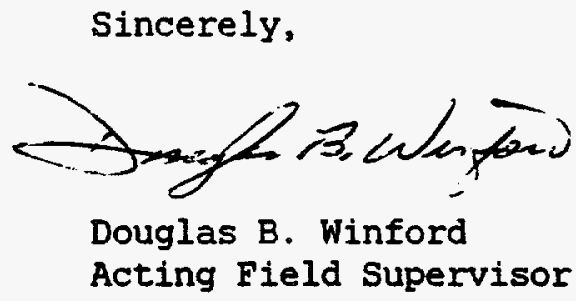

